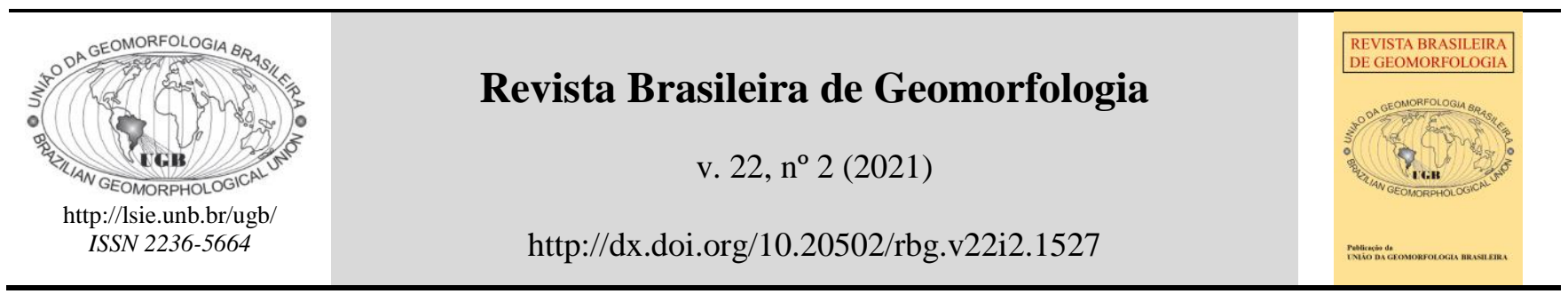

Artigo de Pesquisa

\title{
Geomorfologia do semiárido: proposta metodológica de representação cartográfica e interpretação do relevo em escala de detalhe
}

\author{
Semiarid Geomorphology: a methodological proposal for cartographic \\ representation and interpretation of landforms on a detailed scale
}

Kleber Carvalho Lima ${ }^{1}$ e Cenira Maria Lupinacci ${ }^{2}$

1 Universidade de Pernambuco (UPE), Departamento de Geografia, Garanhuns - PE, Brasil. E-mail: kleber.carvalho@upe.br ORCID: https://orcid.org/0000-0002-9468-2473

2 Universidade Estadual Paulista (UNESP), Departamento de Geografia e Planejamento Ambiental, Rio Claro - SP, Brasil.

E-mail: cenira.lupinacci@unesp.br

ORCID: https://orcid.org/0000-0002-4732-1421

Recebido: 20/09/2018; Aceito: 31/12/2020; Publicado: 10/04/2021

Resumo: O desenvolvimento de uma cartografia do relevo em escala de detalhe no semiárido brasileiro apresenta diversos aspectos a serem considerados, de maneira a subsidiar consistentemente, pesquisas geomorfológicas em contextos locais. Nesse artigo, objetivou-se apresentar uma proposta metodológica de mapeamento geomorfológico de detalhe para setores cristalinos da Depressão Sertaneja semiárida, desenvolvida por meio de estudo de caso. Os procedimentos metodológicos envolveram a preparação da base de dados, análise de manuais de mapeamento geomorfológico pré-existentes, trabalhos de campo, elaboração de chave de interpretação e a representação gráfica das formas de relevo. Desse modo, foram representados atributos morfográficos e morfométricos do relevo, bem como a hidrografia, topografia, feições antrópicas, litologia, cronologia e elementos estruturais. O mapeamento geomorfológico elaborado contribuiu para o entendimento da organização espacial das formas de relevo nas áreas de estudo, além de contribuir com a interpretação dos fatos geomorfológicos. Assim, acredita-se que os procedimentos técnicos desenvolvidos podem ser aplicados em áreas com características semelhantes, ou ainda, serem adaptados a diferentes contextos no próprio semiárido.

Palavras-chave: Cartografia temática; Cartografia Geomorfológica; Depressão Sertaneja.

\begin{abstract}
The geomorphological cartography at a scale of detail in the Brazilian semiarid presents several aspects to be considered, in order to consistently subsidize geomorphological research in local contexts. In this paper, we aim to present a methodological proposal for detailed geomorphological mapping in crystalline sectors of the Sertaneja Depression (Brazilian semi-arid), developed through a case study. The methodological procedures involved the preparation of the database, analysis of pre-existing geomorphological mapping manuals, fieldwork, elaboration of the geomorphological interpretation key, and the graphic representation of the landforms. In this way, morphographic and morphometric attributes were represented, as well as hydrography, topography, anthropogenic landforms, lithology, chronology, and structural elements. The geomorphological mapping contributed to the understanding of the spatial organization of landforms in the study areas, in addition to contributing to the interpretation of geomorphological facts. Thus, we believe that technical procedures can be used in similar areas or even adapted to different contexts in the semiarid itself.
\end{abstract}

Keywords: Thematic cartography; Geomorphological mapping; Sertaneja Depression.

\section{Introdução}


A problemática do mapeamento geomorfológico no semiárido brasileiro foi anteriormente levantada por autores como Ferreira (2010), Lima, Cunha e Perez Filho (2013), Lima (2014) e Lima et al. (2014), que apontaram diversas questões relacionadas ao seu desenvolvimento, especialmente àquelas referentes a carência e acessibilidade a materiais que servem de base para os mapeamentos. Dentre esses materiais, podem ser citadas fotografias aéreas, imagens orbitais, cartas topográficas em escala maior que 1:100.000 e cartas geológicas de detalhe. Além disso, levanta-se a ausência de propostas metodológicas adequadas ao contexto regional, no sentido de padronizar a classificação das formas e a representação do relevo no semiárido.

Sobre o aspecto da cartografia geomorfológica, considera-se que, além do material de base, são necessários cuidados que ultrapassam os conhecimentos técnicos e operacionais da cartografia e do SIG, no sentido de garantir a correta interpretação dos fatos geomorfológicos pretéritos e atuais (GUSTAVSSON; KOLSTRUP; SEIJMONSBERGEN, 2006). Dessa maneira, faz-se primordial o conhecimento teórico e prático das propriedades e dos processos envolvidos na elaboração do relevo a fim de que o mapeamento represente de forma precisa e coerente a morfologia.

Do ponto de vista das metodologias apresentadas em manuais de mapeamento geomorfológico, Pavlopoulos, Evelpidou e Vassilopoulos (2009) colocaram que a diversidade de propostas é um aspecto que pode comprometer a representação cartográfica do relevo, uma vez que existem diferentes propósitos por parte dos pesquisadores com esse tipo de cartografia, além, principalmente, da grande variedade de terrenos a serem mapeados. Nesse ponto são pertinentes as discussões realizadas por Lima et al. (2014) que propõem a flexibilização das propostas de mapeamento para a representação do relevo no semiárido brasileiro.

Para além da flexibilização dos manuais preexistentes, o objetivo desse artigo é apresentar uma metodologia de mapeamento geomorfológico de detalhe para o cenário de terrenos cristalinos da Depressão Sertaneja semiárida, a partir da discussão de conceitos e elaboração de simbologias adaptadas a esse contexto, predominante no interior do Nordeste do Brasil. Nesse intuito, tomou-se por base um esquema representativo do modelado no semiárido cristalino e desenvolveu-se o estudo de caso em duas bacias hidrográficas no semiárido baiano, cuja diversidade de fatos geomórficos a serem representados possibilitou a exploração significativa das simbologias.

\section{2. Área de Estudo}

As áreas de estudo estão localizadas na porção nordeste do semiárido da Bahia (Figura 1), especificamente no município de Santaluz, sendo a bacia hidrográfica do Riacho da Cruz (BHRC) e a bacia do Riacho da Várzea (BHRV). A BHRC apresenta área de $65,9 \mathrm{~km}^{2}$ e a BHRV apresenta $54,3 \mathrm{~km}^{2}$ de área. Essas bacias hidrográficas apresentam características semelhantes às apresentadas no esquema representativo do relevo na Depressão Sertaneja (SILVA, 1986) (Figura 2).

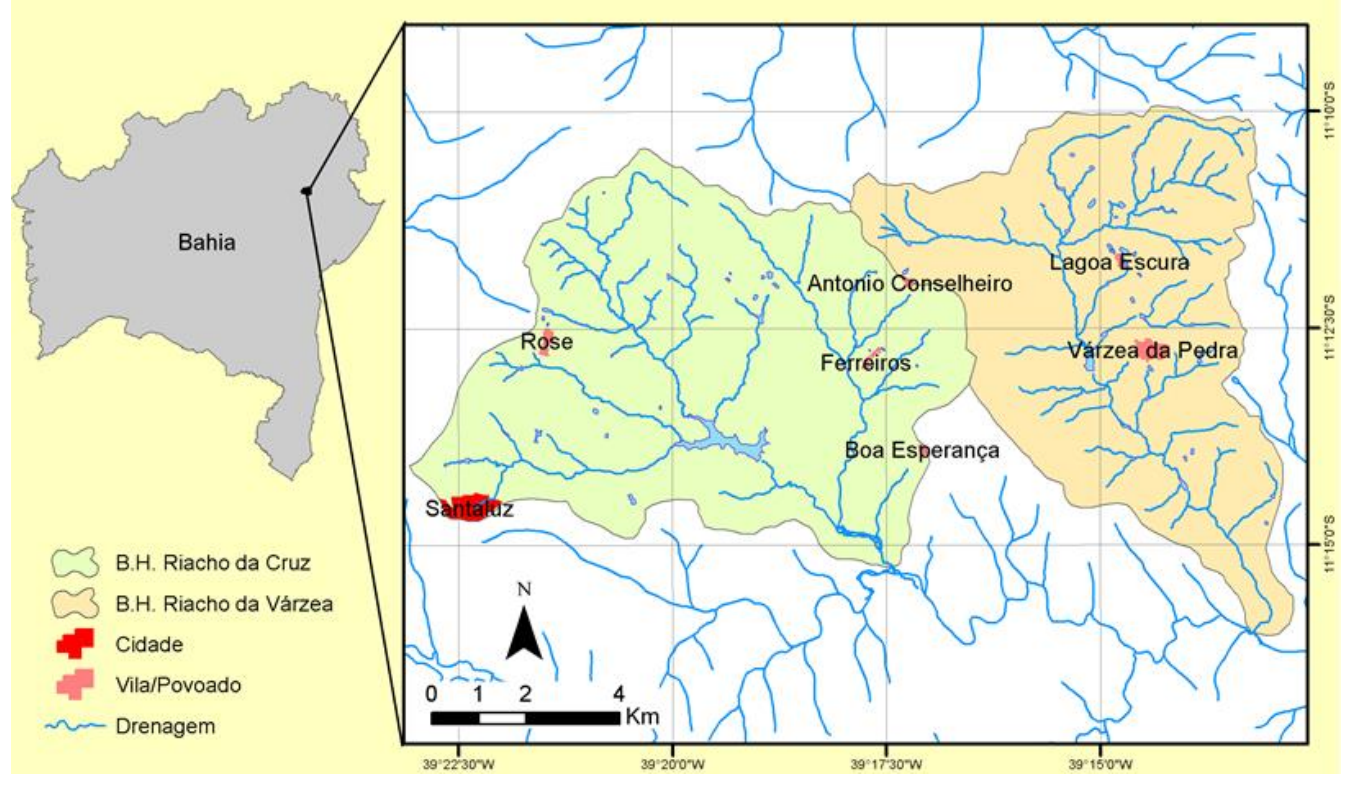

Figura 1. Mapa de localização das áreas de estudo. 


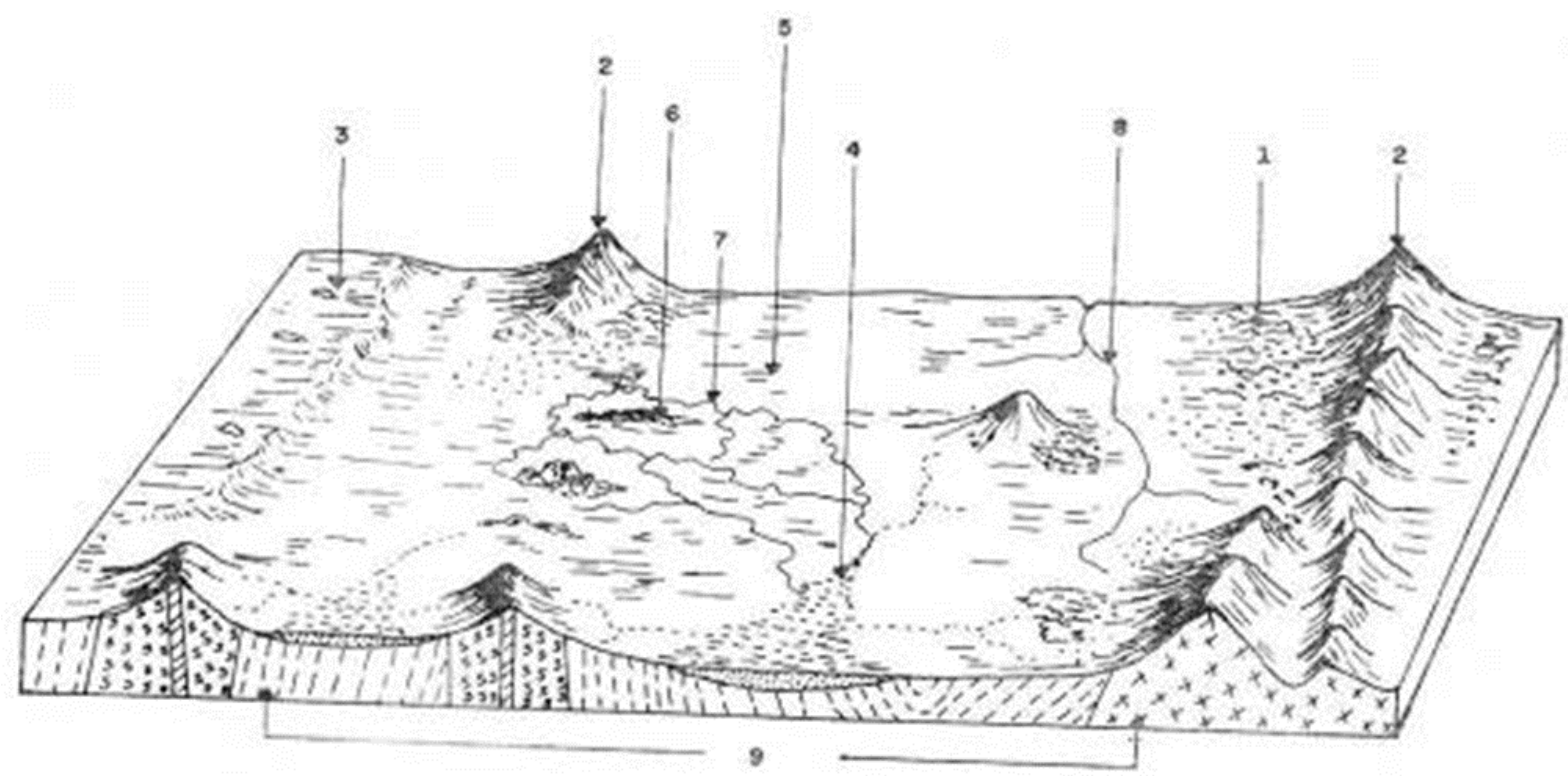

Figura 2. Esquema representativo da Depressão Sertaneja: 1. Tálus; 2. Inselbergue e elevações residuais; 3. Interflúvios planos; 4. Áreas de acumulação; 5. Planos com espraiamento de detritos; 6. Lajedos e acúmulos de blocos; 7. Escoamento difuso; 8. Escoamento concentrado; 9. Diferenças litológicas. Fonte: Silva (1986).

No modelado regional, predominam formas de relevo resultantes de processos de aplainamento como inselbergues, pedimentos, vales de fundo plano e planícies aluviais, elaboradas sobre o embasamento cristalino. As litologias estão agrupadas no domínio estrutural do Complexo Santaluz (Arqueano Médio Inferior - >3,0 Ga), localmente composto por gnaisses, ortognaisses e intrusões de granitos e sienitos (CPRM, 2010). Ocorrem ainda rochas metavulcânicas e metassedimentares do Greenstone Belt do Itapicuru. Do ponto de vista estrutural, ocorrem falhas e lineamentos estruturais com sentido predominante NO-SE que favoreceram o alinhamento dos topos dos inselbergues e a orientação dos canais de drenagem.

Nas bacias em estudo, o clima Semiárido apresenta temperatura média anual de $24^{\circ} \mathrm{C}$ e pluviosidade média anual de 537,9 mm (SEI, 1999). O período chuvoso corresponde aos meses entre novembro e março e o período seco entre julho e outubro. Ainda assim, o regime de chuvas é irregular, com estiagens recorrentes, agravadas nos períodos de atuação de El Niño (MARENGO; CUNHA; ALVES, 2016). Ocasionalmente, podem ocorrer precipitações em regime de torrente, típicas de regiões secas, associadas a pequenas células de baixa pressão atmosférica (GRAFF, 1988). Em decorrência do comportamento pluviométrico, a rede de drenagem em ambas as bacias é composta por canais de drenagem efêmeras, cujos fluxos hídricos ocorrem apenas durante e imediatamente após as chuvas mais extremas.

\section{Materiais e Métodos}

A preparação da base para o mapeamento incluiu a seleção de dados topográficos, geológicos e imagens orbitais. Idealmente, todos esses dados devem estar na mesma escala cartográfica, segundo os propósitos da pesquisa a ser desenvolvida. Contudo, em se tratando do semiárido brasileiro, faz-se necessárias adaptações quanto às bases do mapeamento, dadas as dificuldades anteriormente discutidas por Lima, Cunha e Perez Filho (2013). No contexto das bacias em estudo, adotou-se a escala 1:40.000, cujos procedimentos realizados e materiais utilizados, de maneira sequencial, foram:

(i) Seleção de fotografias aéreas da Companhia Baiana de Pesquisa Mineral (CBPM) em escala 1:60.000, sobrevoo realizado no ano de 1974. Devido à qualidade da resolução das fotografias aéreas, foi possível aplicar a ferramenta zoom (2x), a partir da escala original, no intuito de ajustá-las a escala de trabalho, sem comprometer a visualização dos elementos imageados e eventuais distorções nos pixels da imagem. Considera-se que a utilização de fotografias aéreas é fundamental para o mapeamento do relevo pois a tridimensionalidade proporcionada pelos pares estereoscópicos contribui para a interpretação, a mais fidedigna possível, das propriedades do relevo; 
(ii) Montagem dos pares anaglifos de fotografias aéreas no StereoPhoto Maker 4.34 com o auxílio de óculos 3D com lentes azul e vermelha, segundo procedimentos descritos por Souza e Oliveira (2012). Os pares foram georreferenciados no ArcGIS® e, sequencialmente, realizou-se a identificação preliminar das formas de relevo;

(iii) Utilização de imagens Digital Globe do ano de 2004 em escala de detalhe, disponíveis no banco de dados do software ArcGIS® (Menu - add data . Add base map _ Imagery). As imagens disponíveis nesse banco de dados são as mesmas apresentadas pelo Google Earth®) (LIMA; LUPINACCI, 2019), e possuem a vantagem de serem acessadas gratuitamente e diretamente no software, desde que conectado à rede e a possibilidade de se extrair os elementos mapeados em escalas que podem chegar até 1:3.000;

(iv) Análise de manuais de mapeamentos geomorfológicos, com vistas a criação e adaptação de simbologias (Tabela 1), bem como a organização da legenda. Nesse contexto, analisaram-se as propostas de Tricart (1965), Verstappen e Zuidam (1975) e IBGE (2009). A respeito da adaptação de simbologias, Cunha (2011) observou que este é um procedimento adequado, sendo necessário em condições específicas do terreno, assim como a criação de simbologias não contempladas nas propostas existentes;

(v) Extração dos elementos topográficos da carta SC.23-Y-D-III (Santaluz), elaborada pela SUDENE em 1975, em escala 1:100.000. Adicionalmente, foram extraídas curvas de nível a partir do Modelo Digital de Elevação (MDE) da missão SRTM (Shuttle Radar Topography Mission), com o intuito de comparar os dois produtos e gerar curvas adequadas à escala de trabalho, com equidistância de 20 metros. Para o contexto do semiárido, acredita-se que a utilização dos modelos de elevação sejam uma alternativa à ausência de cartas topográficas com maiores detalhes, embora devam ser utilizadas de maneira cautelosa (conforme procedimentos técnicos apontados por Lima, Cunha e Perez Filho, 2013; Lima e Cunha, 2014);

(vi) Organização dos arquivos vetoriais (ponto, linha e polígono) na base de dados, em função da escala, o que permitiu as edições necessárias para a adaptação dos símbolos ao ambiente digital em SIG (PASCHOAL; CONCEIÇÃO; CUNHA, 2010; OTTO; GUSTAVSSON; GEILHAUSEN, 2011);

(vii) Realização de trabalho de campo com o intuito de verificar as formas de relevo mapeadas, fotografá-las e corrigir possíveis erros de interpretação. Ainda, tomaram-se pontos de controle com o auxílio de aparelho GPS (Global Positioning System) para a calibragem do mapa;

(viii) Elaboração da chave de interpretação (Figuras 3, 4 e 5) com o intuito de auxiliar o reconhecimento das formas de relevo típicas do semiárido, contendo as definições geomorfológicas adotadas nessa pesquisa, a simbologia proposta, fotografias das formas de relevo e sua visualização nas imagens Digital Globe.

\subsection{Representação dos elementos do relevo}

Propõe-se que a representação do relevo em escala de detalhe deva ser realizada a partir da utilização de simbologias lineares que permitam a compreensão dos atributos do relevo e a elucidação dos processos envolvidos na sua elaboração. Os atributos representados dizem respeito a morfografia, morfometria, morfogênese, litologia, cronologia e hidrografia, segundo indicações de Tricart (1965) e Gustavsson, Kolstrup e Seijmonsbergen (2006).

As formas de relevo foram organizadas de acordo à sua gênese, seguindo a organização adotada pelo Manual de Geomorfologia do Instituto Brasileiro de Geografia e Estatística (IBGE, 2009). Têm-se então os modelados de acumulação, de dissecação, de aplanamento e estrutural. Este último, não individualizado em uma categoria na proposta do IBGE, foi adaptado da proposta de Verstappen e Zuidam (1975).

\subsection{Morfografia e morfometria}

Os elementos morfográficos, representados pelas simbologias, apresentam características qualitativas das formas, Gustavsson, Kolstrup e Seijmonsbergen (2006), constituídas por linhas, ponto e polígonos, com cores que remetem aos processos genéticos (Tabela 1). Os elementos morfométricos apresentam características 
quantitativas das feições do relevo, cujas dimensões areais estão presentes na tabela de atributos dos arquivos shapefile. As medidas de extensão, por sua vez, foram representadas no mapa.

Tabela 1. Formas de relevo, fonte das simbologias e cor no sistema RGB.

\begin{tabular}{|c|c|c|}
\hline Forma de relevo & Autor e código da simbologia & Cor (RGB) \\
\hline Leque de desague & Adaptado de Tricart (1965) $100+106$ & \\
\hline Cone de dejeção & Tricart (1965); 56 & R0 \\
\hline Tálus & Autor & $\begin{array}{ll}\text { GyL } \\
\text { B?30 }\end{array}$ \\
\hline Planície aluvial & Adaptado de Verstappen e Zuidam (1975) 4.10 & \\
\hline Ruptura de declive & Adaptado de Verstappen e Zuidam (1975) 3.7 & \\
\hline Ressalto topográfico & IBGE (2009) & \\
\hline Vale em V & Adaptado de Verstappen e Zuidam (1975) 9.12 & 115 \\
\hline Vale com fundo plano & Adaptado de Verstappen e Zuidam (1975) 9.14 & \\
\hline Inselbergue & Adaptado de Verstappen e Zuidam (1975) 3.5 & \\
\hline Paredão rochoso & Verstappen e Zuidam (1975) 3.11 & \\
\hline Lajedo & Autor & R115 \\
\hline Caos de bloco & Autor & G38 \\
\hline Caimento em pedimento & IBGE, 2009 & B0 \\
\hline Superfície de erosão conservada & Tricart (1965) 51 & \\
\hline Superfície de erosão dissecada & Adaptada de Tricart (1965) 53 & \\
\hline Faceta triangular & Adaptado de IBGE (2009) & R115 G0 \\
\hline Superfície estrutural & Autor & B76 \\
\hline Divisor de águas & $\begin{array}{l}\text { Adaptado de Verstappen e Zuidam (1975) } 9.8+ \\
\qquad 14.8\end{array}$ & \\
\hline Vertente irregular & Adaptado de Verstappen e Zuidam (1975) 13.8 & \\
\hline Vertente côncava & $\begin{array}{l}\text { Adaptado de Verstappen e Zuidam (1975) } \\
13.11\end{array}$ & R0 \\
\hline $\begin{array}{l}\text { Comprimento de vertente } \\
\text { irregular }\end{array}$ & Autor & $\begin{array}{l}\text { Bu } \\
\text { B0 }\end{array}$ \\
\hline $\begin{array}{l}\text { Comprimento de vertente } \\
\text { côncava }\end{array}$ & Autor & \\
\hline Comprimento de rampa de tálus & Autor & \\
\hline Incisão de torrente & Adaptado de Tricart (1965) 43 & \\
\hline Anastomose & Adaptado de Verstappen e Zuidam (1975) 4.11 & \\
\hline Drenagem intermitente & Tricart (1965) 82 & \\
\hline $\begin{array}{c}\text { Drenagem efêmera em leito } \\
\text { definido }\end{array}$ & Tricart (1965) 83 & G92 \\
\hline $\begin{array}{c}\text { Drenagem efêmera em leito } \\
\text { indefinido }\end{array}$ & Adaptado de Tricart (1965) 127 & \\
\hline Lagoa intermitente & Adaptado de Tricart (1965) 91 & \\
\hline Ponto cotado & SUDENE (1975) & R230 G152 \\
\hline Curva de nível & SUDENE (1975) & B0 \\
\hline Barramento & $\begin{array}{l}\text { Adaptado de Verstappen e Zuidam (1975) } \\
\qquad 14.55\end{array}$ & \\
\hline Cacimba & Autor & \\
\hline Mineração/Pedreira & $\begin{array}{l}\text { Adaptado de Verstappen e Zuidam (1975) } \\
\qquad 12.21\end{array}$ & $\begin{array}{l}\text { R } 230 \\
\text { G } 0\end{array}$ \\
\hline Estrada não pavimentada & Adaptado de SUDENE (1975) & В 0 \\
\hline Caminho & Adaptado de SUDENE (1975) & \\
\hline Cidade & Adaptado de SUDENE (1975) & \\
\hline Vila/Povoado & Adaptado de SUDENE (1975) & \\
\hline Litologia & CPRM (2004) & Diversas \\
\hline
\end{tabular}


As formas de acumulação estão representadas com preenchimentos que remetem ao tipo de material que as compõem, sendo que, no contexto semiárido das áreas analisadas, predominam acumulações de material com diferentes calibres (Figura 3). Nesse caso, as acumulações são de origem fluvial e mista. As acumulações cujos processos possuem mais de uma gênese foram classificadas como gênese mista. Incluem (i) os cones de dejeção, elaborados por processos ocorridos na vertente por ação do escoamento pluvial; (ii) o tálus, formado por processos de escoamento superficial na vertente e processos gravitacionais e; (iii) a planície aluvial. Com base na definição de planície aluvial semiárida utilizada nessa pesquisa, a simbologia apresenta preenchimento na cor azul, devido à contribuição dos fluxos fluviais efêmeros e na cor marrom, devido à mistura com materiais oriundos dos pedimentos marginais por ação do escoamento superficial.

O modelado de dissecação reúne as formas resultantes do entalhe da rede de drenagem e incluem, representados em verde, (i) as rupturas abruptas de declive, presentes nos inselbergues, (ii) os ressaltos topográficos suaves nos pedimentos, (iii) os vales em forma de $\mathrm{V}$, que ocorrem à montante, nos inselbergues, ou onde a drenagem se instalou sobre falhas e/ou fraturas e; (iv) os vales de fundo plano, associados à superfície de erosão, com predomínio de erosão lateral do vale.

No modelado de aplanamento, em cor marrom, estão reunidas maior parte das formas de relevo presentes no contexto semiárido cristalino (Figura 4). Estão incluídos nesse modelado: (i) os paredões rochosos, compreendidos como as porções das vertentes dos inselbergues com exposição da rocha maciça, onde as linhas verticais simbolizam possíveis caneluras formadas por ação do escoamento preferencial; (ii) os lajedos, representados por polígonos preenchidos com cruzes, como forma de representar a maior resistência aos processos erosivos; (iii) as áreas de caos em bloco, com preenchimento em forma de triângulos com posição aleatória, dando a ideia de fragmentos expostos na superfície por ação da exumação de material saprolítico; (iv) o caimento do relevo em pedimento, representado por uma seta indicando a sua direção; (v) a superfície de erosão conservada, representada por trama horizontal com linhas contínuas, demonstrando baixo grau de dissecação da drenagem; (vi) superfície de erosão dissecada, representada por linhas horizontais descontínuas, representando maior grau de dissecação, decorrente da maior densidade de drenagem; (vii) os inselbergues, representados por polígonos com franja simples na linha externa que os delimita. As linhas internas representam as linhas de cumeada.

Observa-se que, em escala de detalhe, é possível mapear as feições embutidas nos inselbergues como as linhas de cumeada, as formas de vertente, tipos de vale, rupturas de declive, paredão rochoso, tafoni, dentre outras. Ainda, ressalta-se que simbologias que remetem à classificação quanto ao tipo de inselbergue (ver item 3) são possíveis e estão presentes em propostas como a de Tricart (1965). Entretanto, optou-se pela representação dos inselbergues sem remissão à sua tipologia, no sentido de priorizar as feições internas aos mesmos.

As feições estruturais reúnem as formas de relevo cujo controle estrutural e litológico sobrepõe-se a processos morfogenéticos de outra natureza e, representadas em roxo, apresentam: (i) facetas triangulares, representadas por linhas que contornam o limite superior da forma, com triângulos equiláteros ao longo da linha, no interior da forma, que apontam para a base da forma; e (ii) superfície estrutural, representada por trama quadriculada, preenchida por textura que faz remissão ao material grosseiro que recobre a superfície.

Os elementos morfométricos são representados em preto e reúnem (i) os divisores de águas, mapeados nessa pesquisa apenas nos topos dos inselbergues. Nas áreas planas, optou-se por representa-los como o limite das bacias hidrográficas; (ii) as formas de vertente com respectivas medidas de comprimento, apresentam simbologias que remetem ao comportamento do escoamento que tende a ser concêntrico (côncavas) e disperso, nas vertentes irregulares, devido às intercalações entre afloramentos rochosos e manto de intemperismo; e (iii) as medidas de comprimento do tálus. 


\section{Leque de desagüe}

Área de descarga de sedimentos situada na confluência de canais de drenagem

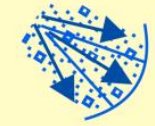

efêmera, em formato de leque. Apresenta carga sedimentar mista, com predomínio de sedimentos grosseiros na parte central do leque e sedimentos finos nas laterais.
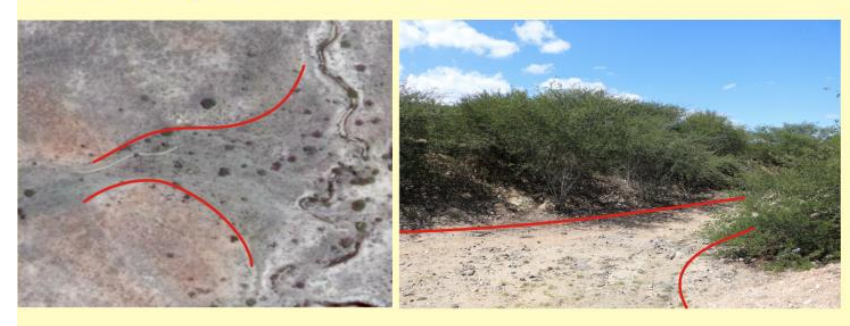

\section{Cone de dejeção}

Área de deposição de material detrítico formado abaixo do canal de escoamento

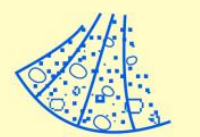

de uma torrente. Ocorrem nas áreas com maiores contrastes de altitudes, como entre as encostas dos inselbergues e os pedimentos.
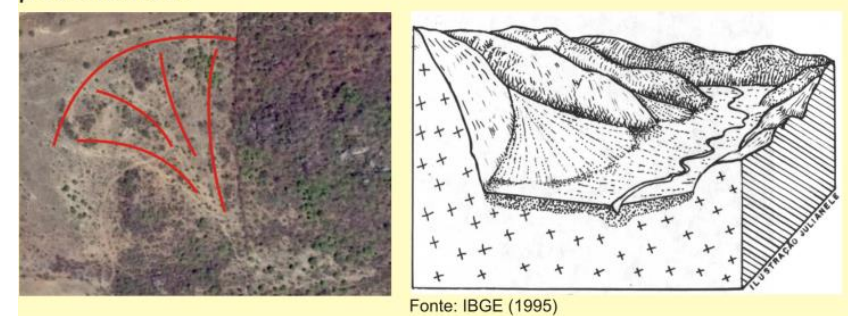

\section{Tálus}

Rampa formada na base da escarpa, composta por blocos rochosos que se

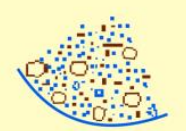
acumularam por ação gravitacional e por sedimentos finos, depositados por ação do escoamento superficial.
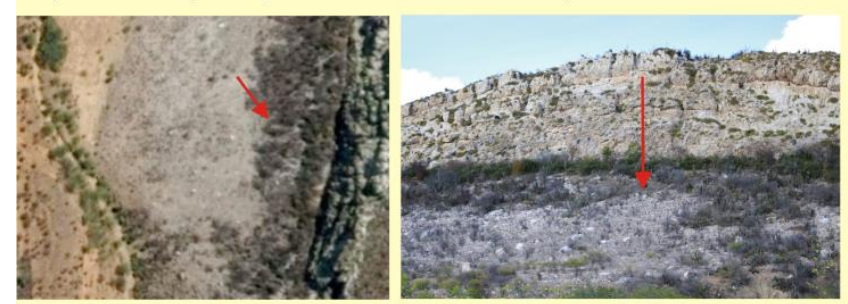

\section{Planície aluvial}

Área de deposição aluvial situada ao longo dos canais de drenagem efêmeros,

espacialmente descontínuas. Seus limites muitas vezes são imprecisos, confundindo-se com porções rebaixadas dos pedimentos, devido ao espraiamento de detritos das vertentes pedimentares.
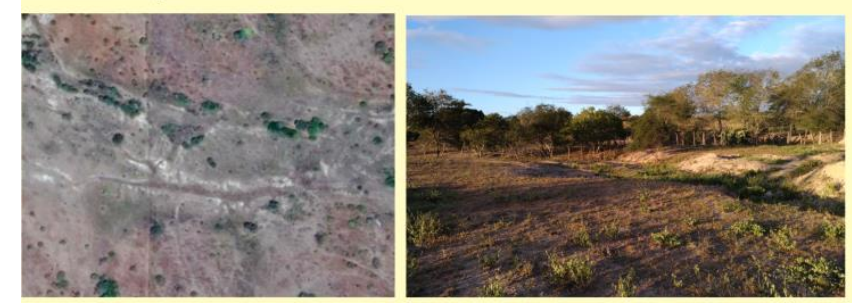

\section{Vale em V}

Vale cuja incisão do talvegue foi maior que a erosão lateral, dando origem a

margens estreitas e vertentes de fortes declividades.

Geralmente associados a canais de primeira ordem, em áreas de maior declividade, ou ainda, quando a drenagem se instala sobre planos de falha e/ou fraturas.
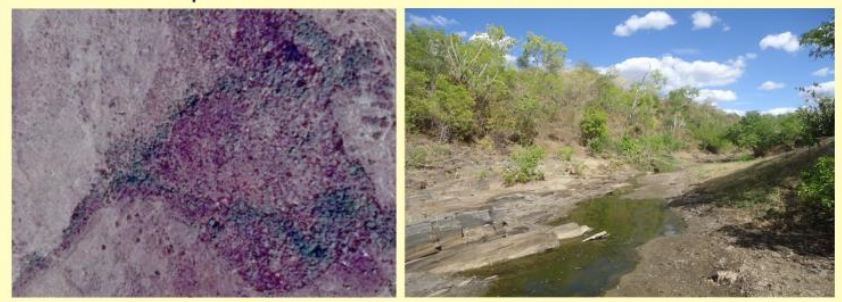

\section{Vale com fundo plano}

Vale cuja erosão lateral dos canais de

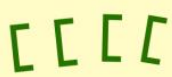
drenagem prevaleceram sobre a incisão

do talvegue, propiciando a ocorrência de margens largas e vertentes com baixa declividade. Ocorrem nas áreas aplainadas dos pedimentos.
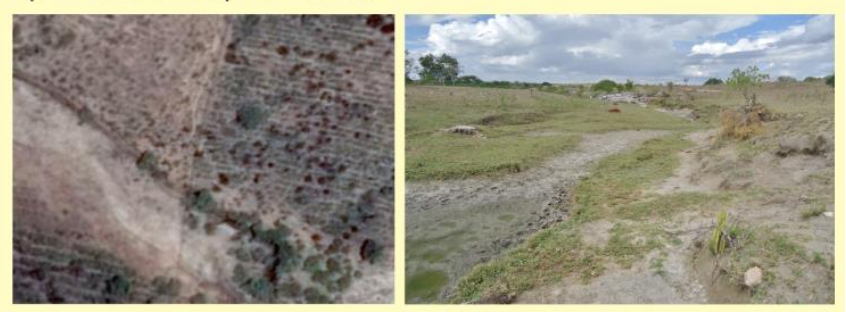

\section{Inselbergue}

Feição residual que ocorre de

maneira isolada em meio aos

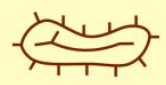
granitos e gnaisses, resultante do processos de pediplanação da superfície.
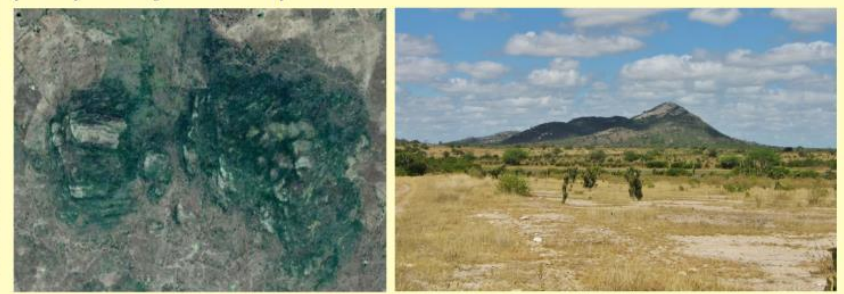

\section{Paredão rochoso}

Área situada nas vertentes dos inselbregues, constituída pela

exposição da rocha constituinte. Em geral, apresenta corpo único ou grandes blocos, com formação de caneluras.
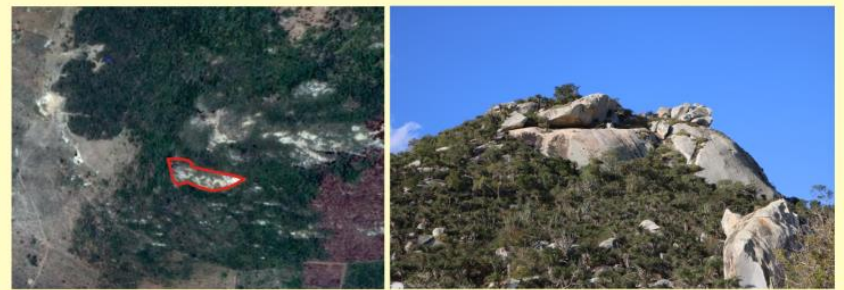

Figura 3. Chave de interpretação de feições de acumulação, de dissecação e de aplainamento. 


\section{Lajedo}

Afloramento de rocha maciça que resulte em formas de relevo tipo bossas, "cascos de tartaruga", "dorsos de baleia", dentre outros, não alcançando as dimensões de um pontão ou inselbergue e sem a conotação genética que esses termos representam.
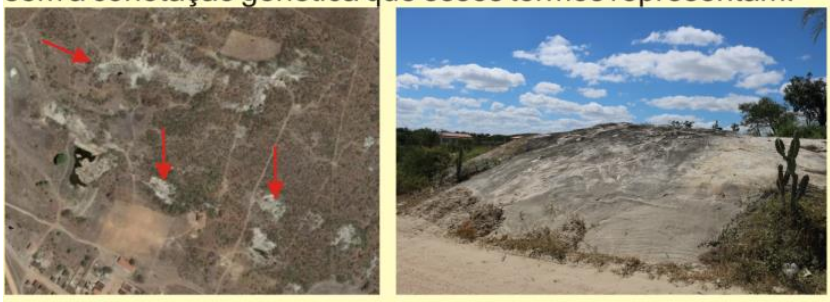

\section{Caos de bloco}

Amontoado de blocos e matacões de forma

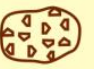
geralmente arredondada, dispostos numa área de dimensão mapeável. São resultantes de processos de subsuperfície, ficando expostos, posteriormente, por ação de processos erosivos de rebaixamento da superfície.
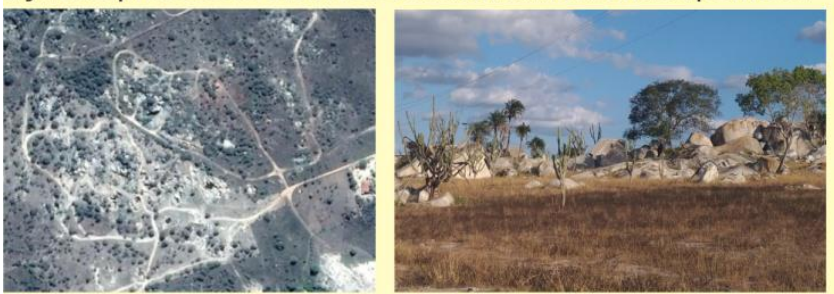

\section{Superfície de erosão conservada ou pedimentos conservados}

Superfície suavemente plana, fracamente dissecada, situada entre as vertentes dos

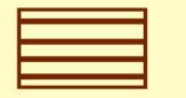
inselbergues e a planície aluvial. É composta por uma fina e descontínua camada de material aluvial que recobre as rochas antigas do embasamento cristalino. Sua gênese está associada a estabilidade cratônica, diferenças litológicas e atuação de clima quente e seco.
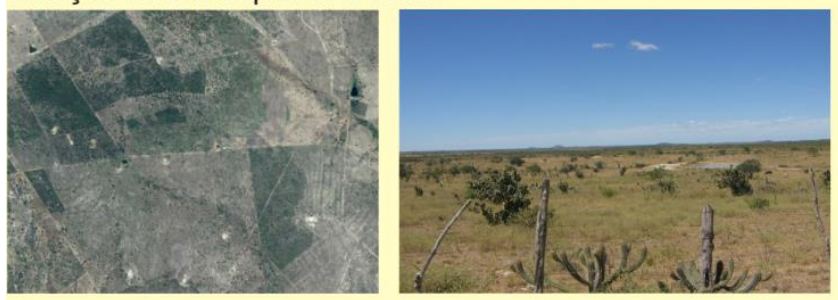

\section{Superfície de erosão dissecada ou pedimentos} dissecados

Superfície suavemente plana, dissecada por ação da rede de drenagem. Posição no

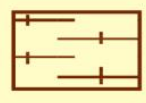
modelado, características de composição e gênese semelhantes aos pedimentos conservados.
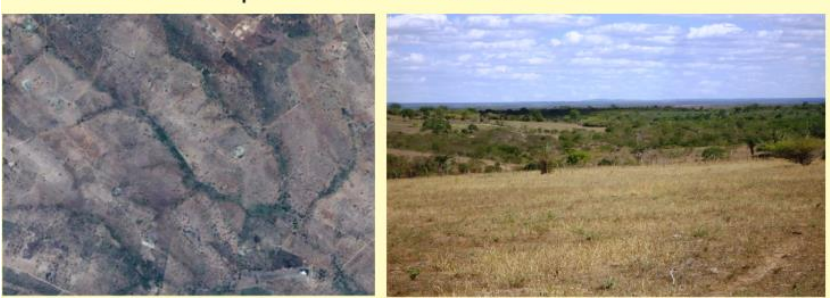

\section{Faceta triangular}

Faces predominantemente triangulares delimitadas por escarpas resultantes

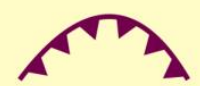

da esculturação de planos de falhas. Sua identificação, muitas vezes, só é possível em pares estereoscópicos de fotografias aéreas.
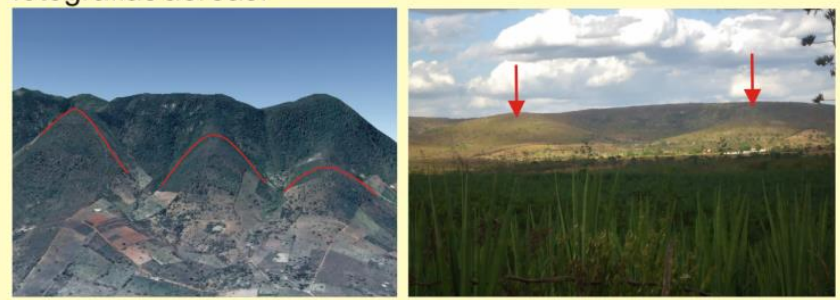

\section{Superfície estrutural}

Superfície onde o trabalho dos agentes erosivos sobre a litologia

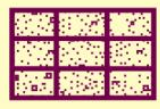

originam formas de relevo que coincidem com a estrutura geológica e evidenciam as camadas duras das rochas. Topograficamente é mais elevada que os terrenos adjacentes, sendo recoberta insipidamente por cascalho, formando uma espécie de pavimento detrítico.
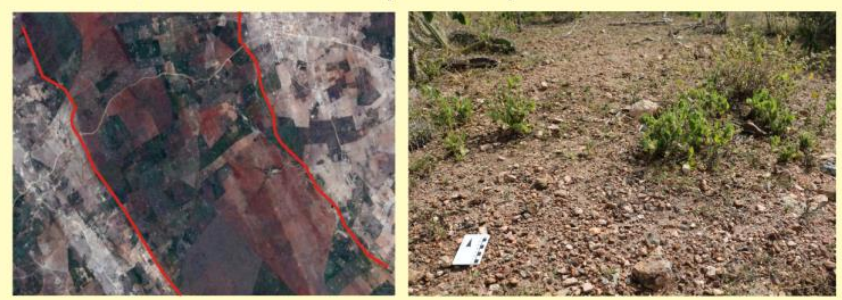

\section{Vertente irregular}

Segmento do terreno com declives

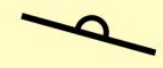

variados e perfil irregular, situado

entre os topos dos inselbergues e a sua base. Seu formato deve-se às alternâncias entre rochas aflorantes e/ou grandes blocos de rochas, soltos na vertente, e o manto intempérico.
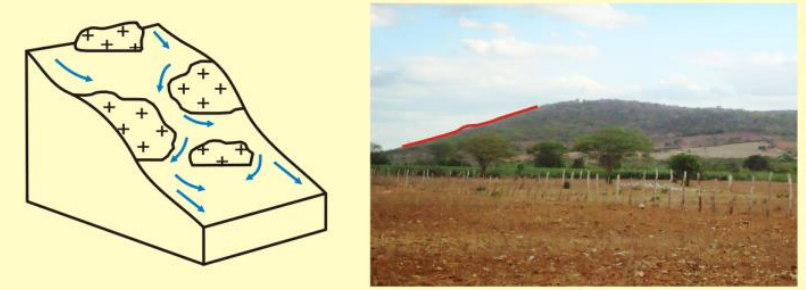

\section{Vertente côncava}

Segmento do terreno com declives variados e perfil côncavo, situado

entre os topos dos inselbergues e a sua base. Devido ao seu formato, tende a acumulação de fluxos do escoamento.
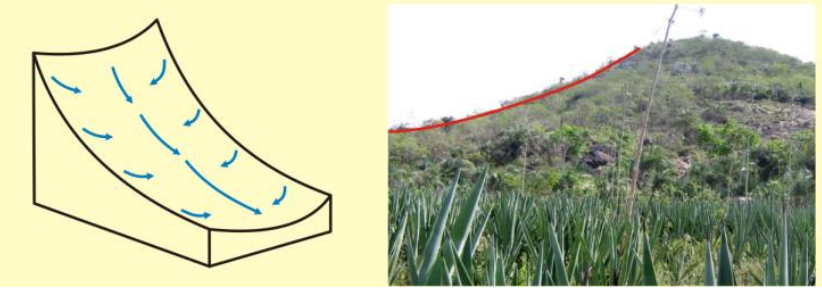

Figura 4. Chave de interpretação de feições de aplainamento, feições estruturais e elementos morfométricos. 


\section{Incisão de torrente}

Espécie de fissura elaborada no terreno por ação do escoamento superficial concentrado, após evento pluviométrico de grande magnitude.
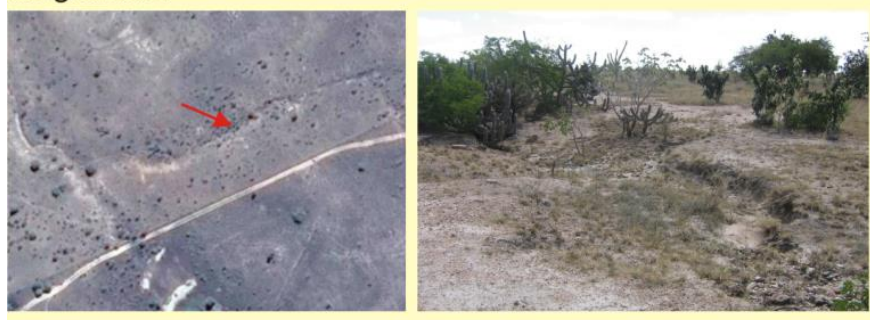

\section{Anastomose}

Padrão complexo de canais de drenagem onde os fluxos de água se dividem e se

reúnem, sem haver, na maioria das vezes, um canal principal.
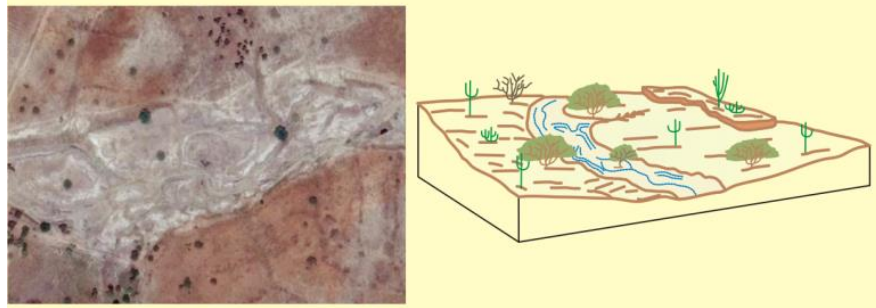

\section{Drenagem fluvial intermitente}

Canal de drenagem cujo fluxo de água permanece contínuo durante a estação chuvosa e, durante a estação seca, esse fluxo cessa.
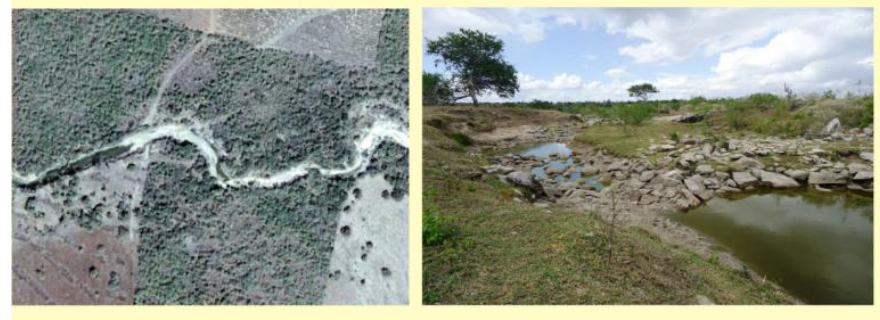

\section{Drenagem fluvial efêmera em leito definido}

Canais de drenagem que permanecem $0 .+1 . .+$ secos durante a maior parte do ano e comportam água apenas no momento das chuvas, Escavações realizadas, geralmente imediatamente após as precipitações. Apesar da nos períodos de estiagem, emáreas efemeridade, os fluxos hídricos conseguem realizar a rebaixadas do terreno, nos leitos secos dos canais de incisão do canal e definir suas margens, sendo identificável drenagem ou nas planícies aluviais, para a obtenção de em produtos orbitais.
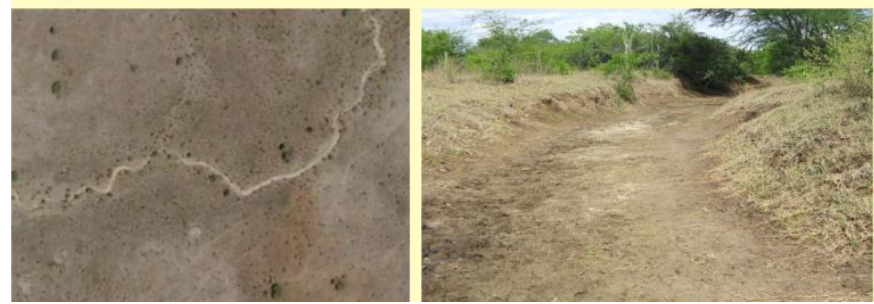

\section{Drenagem fluvial efêmera em leito indefinido}

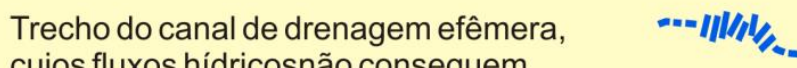
cujos fluxos hídricosnão conseguem

realizar a incisão do talvegue de maneira significativa, dando-lhe aspecto plano, sem margens definidas ou fracamente definidas, não identificável em imagens orbitais.

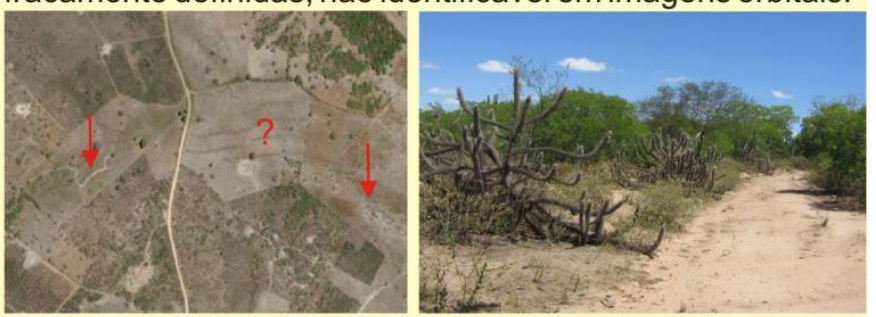

\section{Lagoa intermitente}

Pequenas depressões formadas na superfície que permitem o

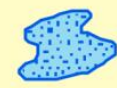

acúmulo de água durante os períodos chuvosos. Durante os períodos de estiagem, a água seca por evaporação.
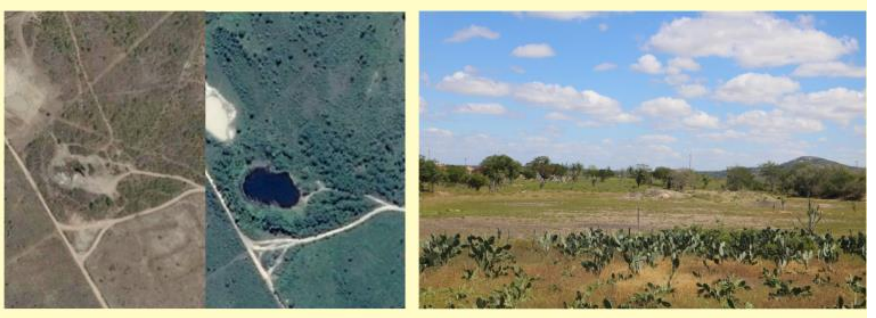

\section{Barramento}

Os termos barragem, represa e açude são utilizados como sinônimos para as

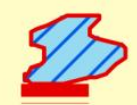
barreiras artificiais construídas nos canais de drenagem, objetivando a retenção de grandes quantidades de água, para abastecimento doméstico e atividades agropecuárias.
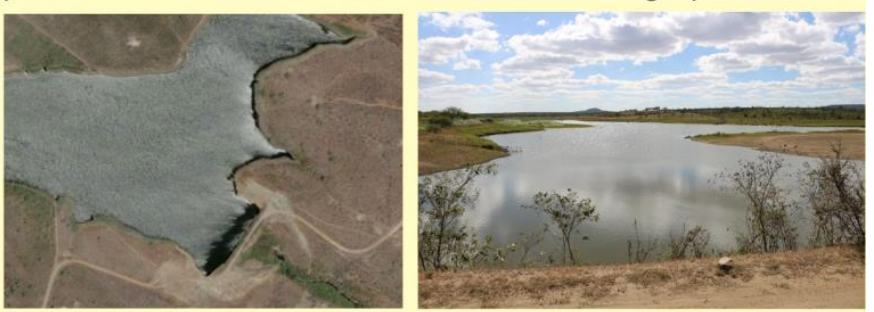

\section{Cacimba}
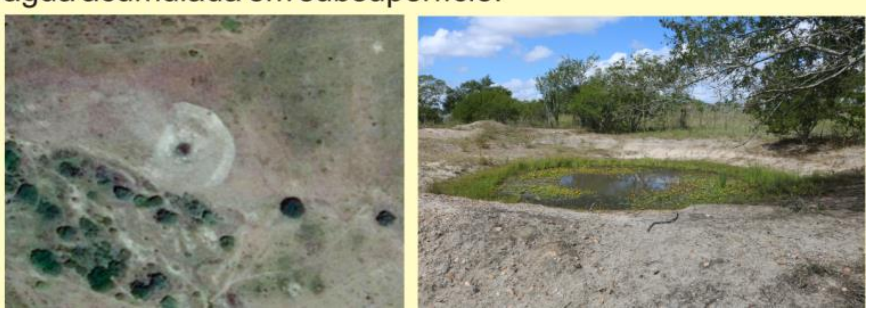

Figura 5. Chave de interpretação de elementos hidrográficos e de feições antrópicas. 


\subsection{Hidrografia e elementos topográficos}

Os elementos hidrográficos são de fundamental importância nos ambientes semiáridos, especificamente com relação às dinâmicas geomorfológicas, conforme as discussões realizadas. Propõe-se então, que os símbolos das feições hidrográficas representem, na cor azul, o comportamento da água nos canais de drenagem e nas lagoas quanto a sua temporalidade, além do trabalho do fluxo fluvial quanto aos processos erosivos (Figura 5). Dessa maneira, congregam: (i) incisões em torrente, representadas por setas que indicam o sentido preferencial do escoamento; (ii) anastomose, representada por uma linha de maior espessura, representando o canal preferencial, e linhas marginais, representando os canais secundários que formam as anastomoses. Nesse caso, as anastomoses indicam o predomínio de migração e erosão lateral; (iii) canais de drenagem intermitentes, representados por uma sequência de linha e pontos que demonstram a existência de períodos com e sem fluxo hídrico; (iv) canais de drenagem efêmeros, subdivididos entre aqueles com margem definida e aqueles com margem indefinida.

Salienta-se que, em algumas situações, as margens não são passíveis de identificar nas imagens, apenas em campo (ver chave de interpretação). Assim, os canais efêmeros com margens definidas estão representados por linhas pontilhadas, demonstrando a casualidade de fluxos hídricos e, nos trechos onde as suas margens não são definidas, estão representados por linhas no sentido transversal à linha do canal; (v) lagoas intermitentes, representadas por polígono com preenchimento azul claro e pontos espaçados, no sentido de representar a intermitência do corpo hídrico.

Os elementos topográficos, representados pela cor laranja, indicam a variação altimétrica do relevo por meio de curvas de nível e de pontos cotados. São elementos fundamentais que auxiliam na interpretação do relevo, especialmente ao demonstrarem o contraste topográfico entre os pedimentos e os inselbergues.

\subsection{Feições antrópicas}

A representação de feições antrópicas está na dependência dos objetivos do pesquisador ao utilizar o mapa geomorfológico. Nessa pesquisa, as feições antrópicas representadas estão diretamente relacionadas à sua interferência nas dinâmicas do relevo, especialmente as de maior impacto sobre o sistema fluvial local. Representadas em vermelho, incluem; (i) os barramentos, simbolizados por uma linha e o corpo hídrico em polígono, preenchido em azul claro e hachuras e contorno em vermelho; (ii) as cacimbas, representadas por círculos concêntricos. Nessa pesquisa, optou-se por mapear apenas aquelas abertas no leito dos canais de drenagem e/ou na planície aluvial; (iii) as pedreiras de extração de granito, representadas pontualmente com o símbolo clássico dessa atividade econômica; (iv) as estradas não pavimentadas e os caminhos, cuja representação dão a ideias de menor e menor largura, respectivamente, bem como da intensidade de tráfego; e (v) as áreas urbanas, representadas por polígonos com preenchimento sólido e transparência de 30\% para a cidade (maior densidade de urbanização) e polígonos hachurados com linhas diagonais estreitas, para as vilas e povoados.

\subsection{Litologia e cronologia}

Propõe-se a representação da litologia por meio de polígonos com preenchimento sólido, com as cores da base geológica adotada, quando essas forem representadas dessa maneira. Nessa pesquisa, as cores originais da litologia foram mantidas, sendo adicionadas as numerações correspondentes, com o intuito de facilitar a sua leitura, uma vez que as cores dos conjuntos litológicos são muito semelhantes. Contudo, observa-se que existem outras opções de representação desse elemento, estando isso na dependência das características das áreas mapeadas e dos objetivos do pesquisador.

As informações cronológicas se referem a litologia, dada a dificuldade de se obter dados da idade da forma de relevo. Nesse caso, propõe-se a utilização de dados geológicos preexistentes, onde a idade pode ser inserida na legenda, como no caso dessa pesquisa, ou pontualmente, no próprio mapa, quando da existência de informações obtidas em campo.

\section{Resultados e interpretações geomorfológicas do mapeamento}

O mapeamento geomorfológico contribuiu de maneira significativa para o entendimento da organização espacial das formas de relevo nas áreas de estudo, além da interpretação dos fatos geomorfológicos. Dessa maneira, são apresentados a legenda final (Figura 6), bem como exemplos dos atributos do relevo em setores representativos das duas bacias. 


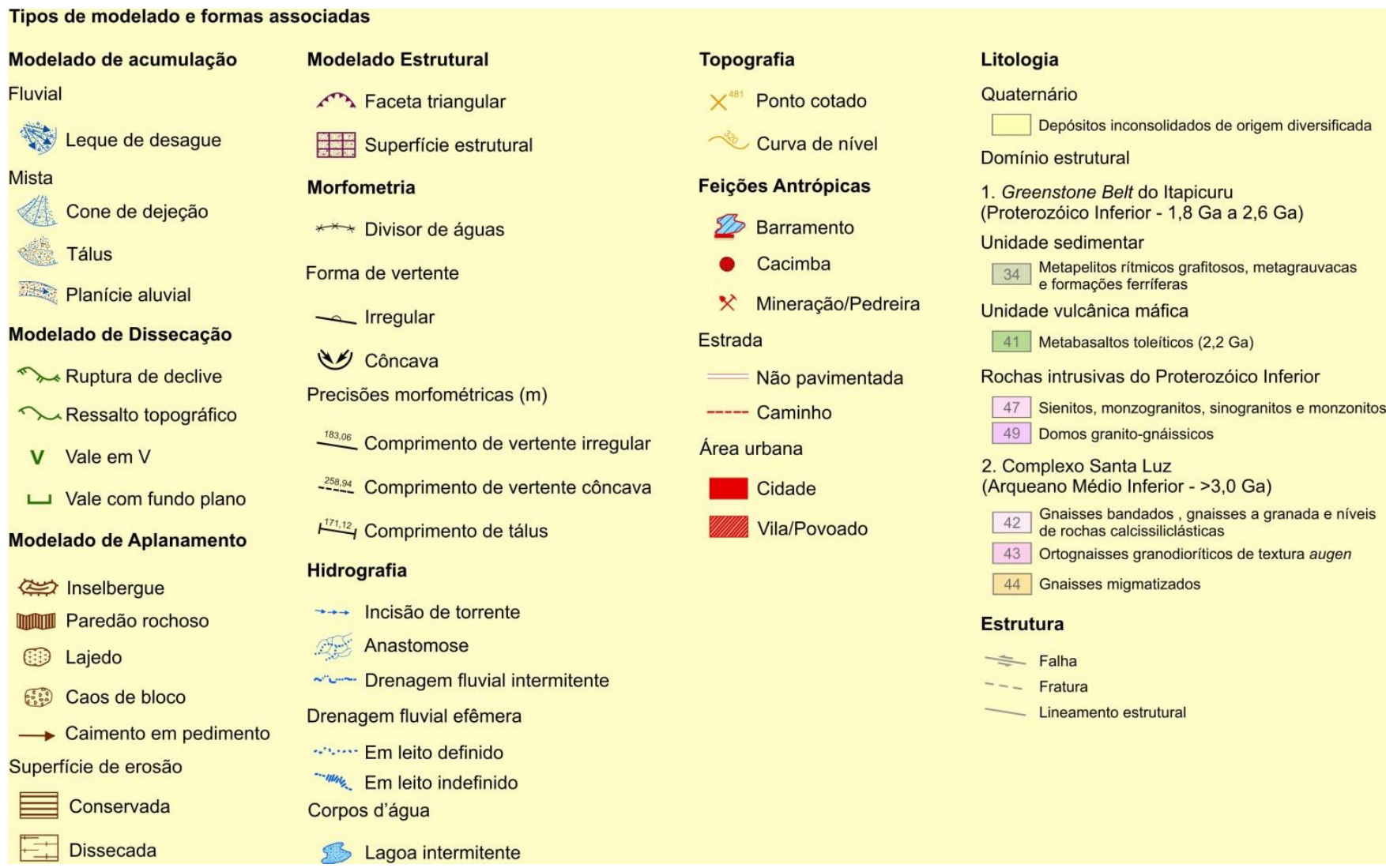

Figura 6. Proposta de legenda para o mapa geomorfológico.

Na BHRC, ocorrem dois inselbergues, sendo um denominado localmente de Serra Branca (Figura 7), desenvolvidos sobre sienitos, e outro, sem nomenclatura definida, situado nas proximidades do povoado de Rose, recoberto pela vegetação de caatinga. Na BHRV ocorre o inselbergue localmente denominado de Serra da Matina (Figura 8), elaborado sobre intrusões granito-gnáissicas que formam regionalmente o Domo do Ambrósio.

Predominam vertentes irregulares devido, em muitos casos, a alternância entre paredões rochosos e manto intempérico, e vertentes côncavas. Nesses casos, os inselbergues não chegam a formar tálus, sendo o contato da sua base direto com os pedimentos mais elevados. Os inselbergues apresentam lineamentos estruturais que favoreceram o encaixamento das drenagens de primeira ordem e o desenvolvimento de vales em V. A esculturação das escarpas de falha da Serra da Matina propiciou a elaboração de facetas triangulares interrompidas lateralmente por canais efêmeros e cones de dejeção (Figura 8).

As superfícies de erosão, no contexto das bacias em estudo, constituem-se dos pedimentos que representam a feição do relevo predominante. Ocorrem em dois níveis topográficos na BHRC, sendo o mais alto em atitude entre 360 e 380 metros e o mais baixo entre 300 e 360 metros. Trata-se de dois níveis conservados (Figura 9) com relação aos processos de dissecação fluvial, predominando fundos de vale planos com canais de drenagem efêmera e topografia suave, modelada sobre estruturas com elevada densidade de lineamentos.

Por outro lado, na BHRV ocorrem dois níveis de pedimentos (Figura 10), sendo o mais elevado conservado, com altitude entre 380 e 420 metros, e o nível mais baixo dissecado por ação da dissecação fluvial, situa-se entre 280 e 380 metros de altitude. O nível dissecado é estreito e alongado, no sentido dos principais lineamentos estruturais.

A superfície estrutural corresponde a uma superfície de erosão disposta latitudinalmente entre as duas bacias hidrográficas, elaborada sobre metabasaltos da unidade vulcânica máfica (Figura 11), integrante do Greenstone Belt do Itapicuru. Essa superfície é recoberta insipidamente pelo seu manto intempérico cujos sedimentos grosseiros, como cascalho, formam uma espécie de pavimento detrítico. Topograficamente é mais elevada que os terrenos adjacentes (340 e 380 metros) e, devido à sua alta resistência a erosão, possui poucos canais de drenagem. 


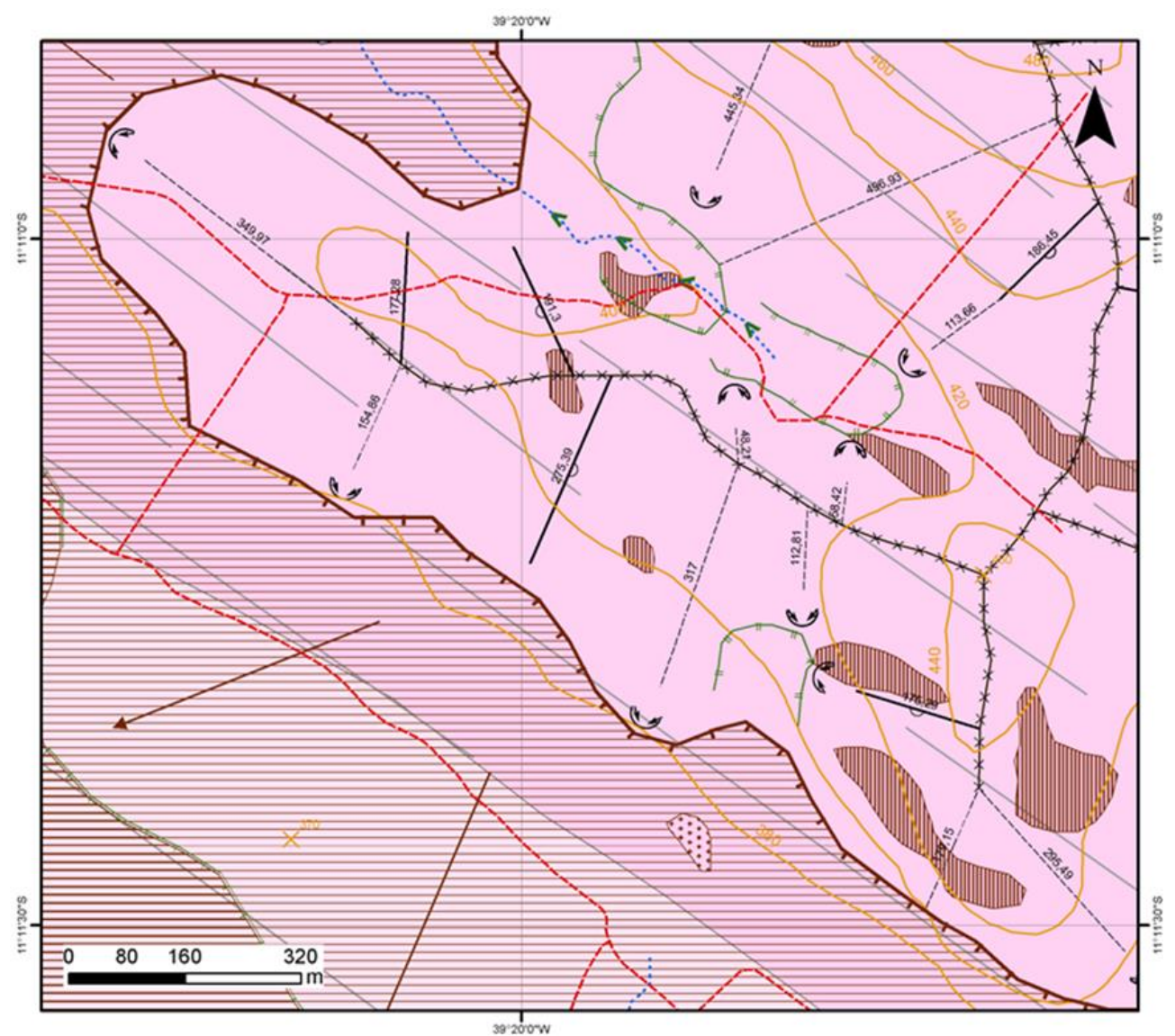

Figura 7. Mapa geomorfológico da BHRC com trecho da Serra Branca. A legenda encontra-se na Figura 6.

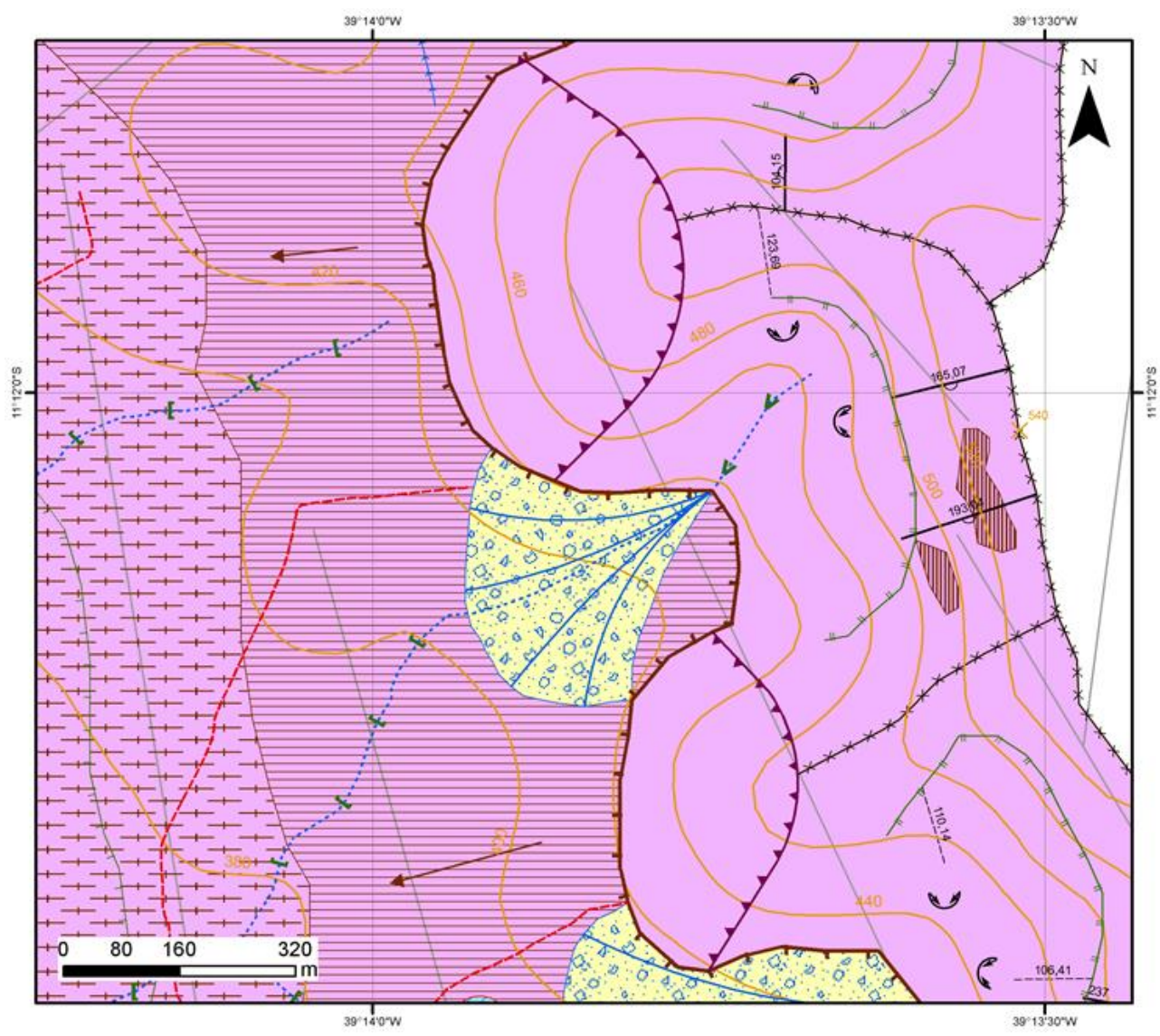

Figura 8. Mapa geomorfológico da BHRV com trecho da Serra da Matina. A legenda encontra-se na Figura 6. 


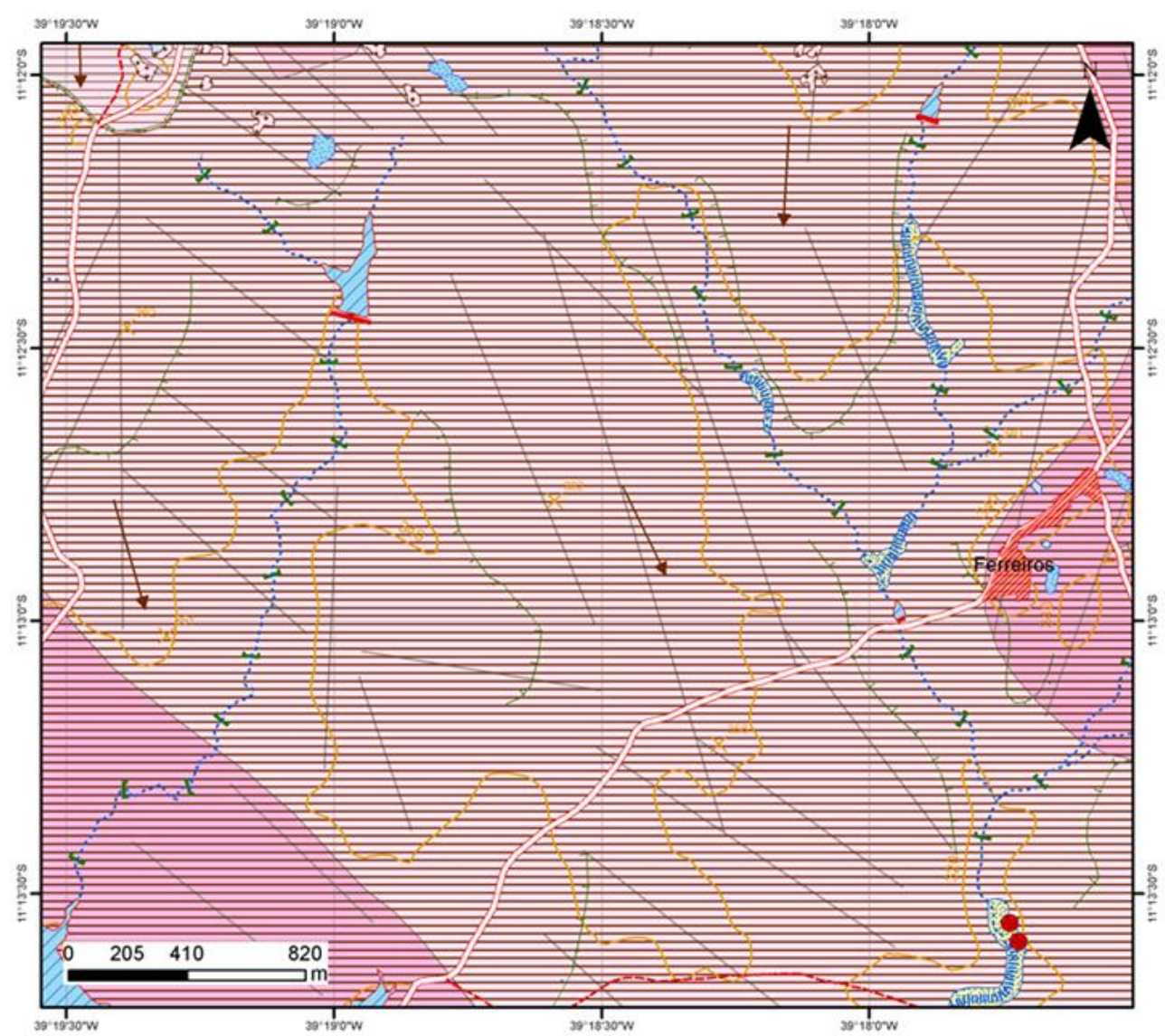

Figura 9. Mapa geomorfológico da BHRC com trecho da superfície de erosão. A legenda encontra-se na Figura 6.

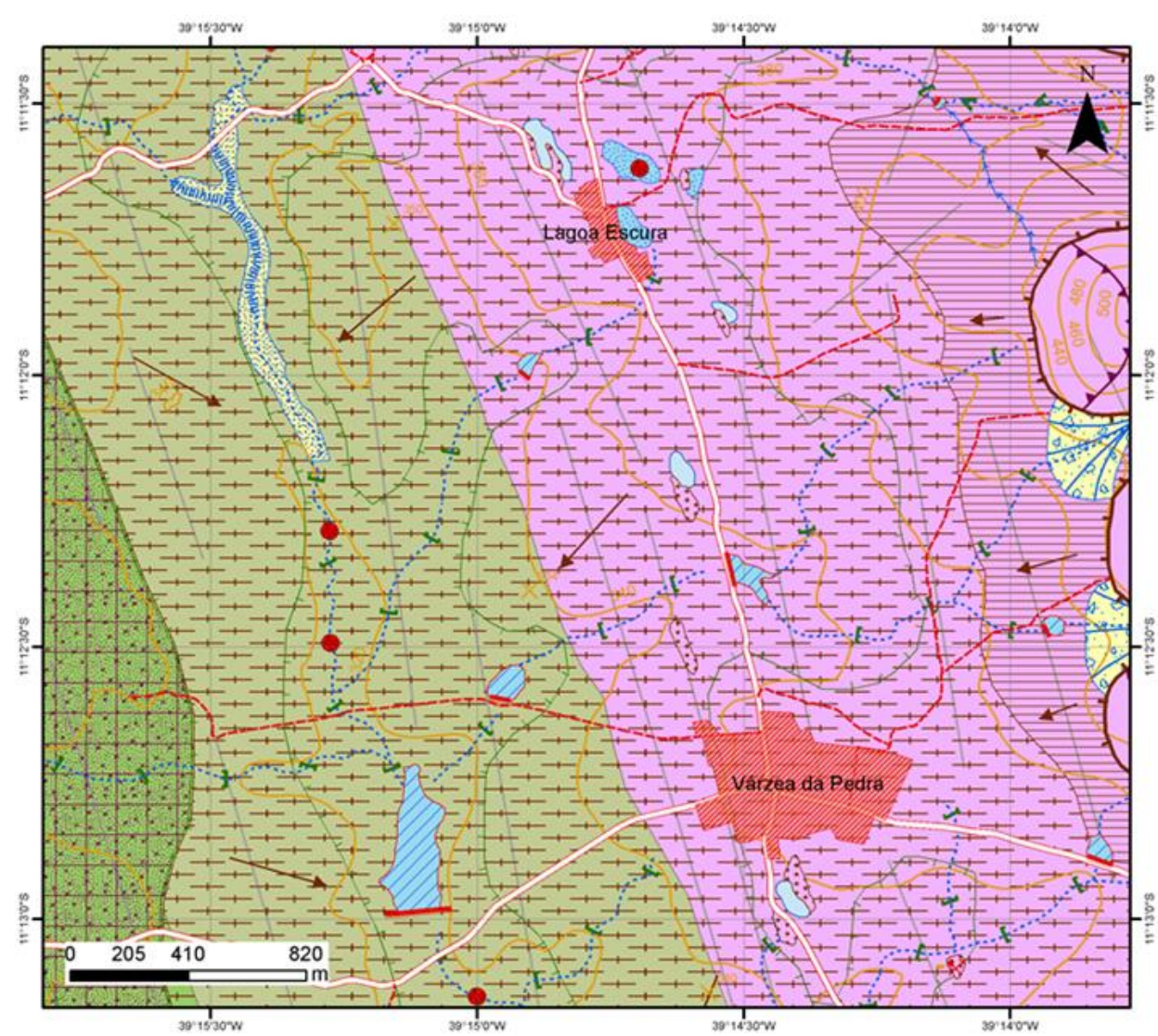

Figura 10. Mapa geomorfológico da BHRV com trecho da superfície de erosão conservada e dissecada. A legenda encontra-se na Figura 6. 


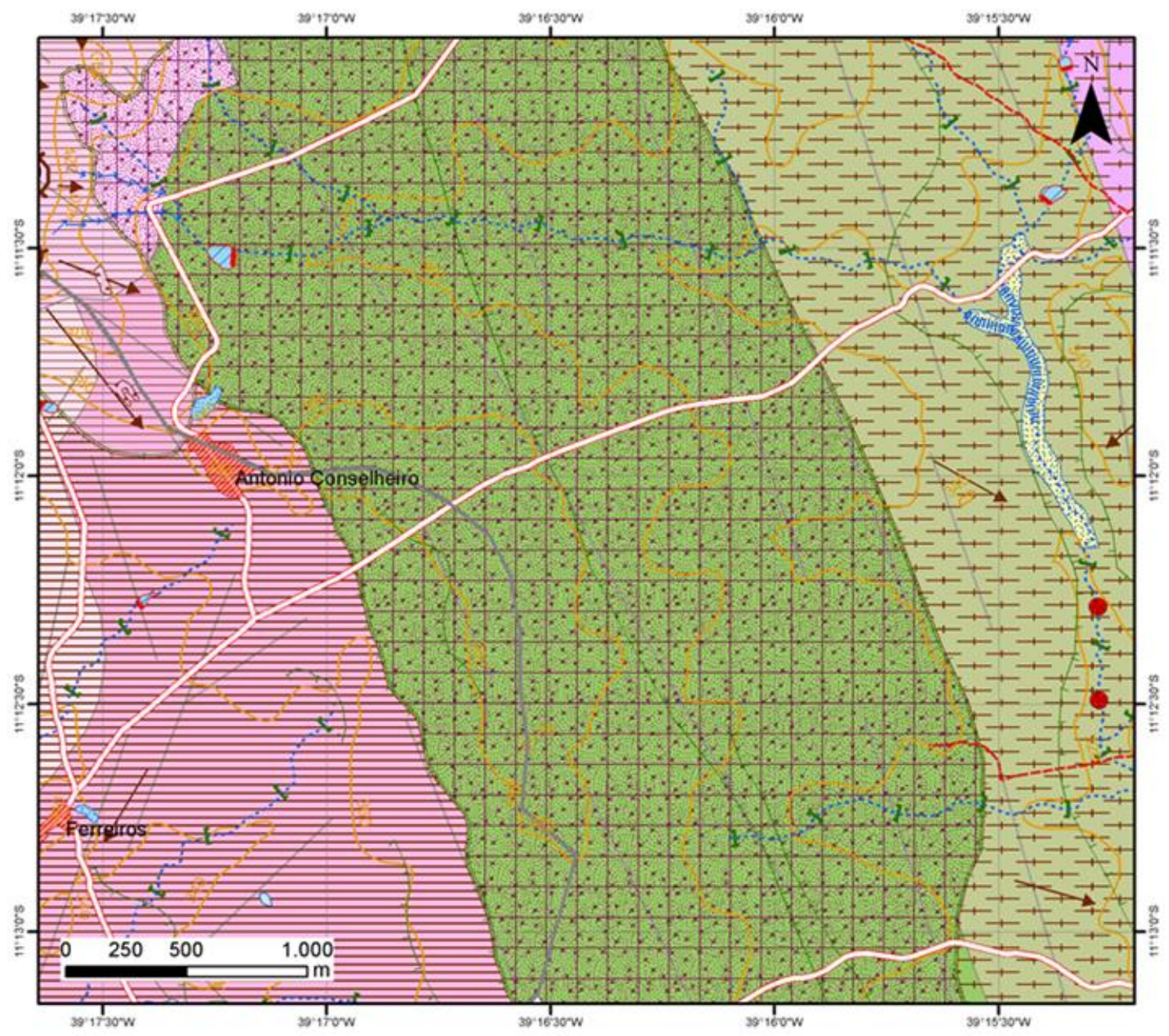

Figura 11. Mapa geomorfológico de trecho da superfície estrutural entre as duas bacias em estudo. A legenda encontra-se na Figura 6.

Dispostas espacialmente ao longo dos cursos efêmeros de maneira descontínua, as planícies aluviais são estreitas e, muitas vezes constituem-se em áreas de espraiamento de sedimentos oriundos dos pedimentos. Por vezes, o canal de drenagem não possui margens definidas, fazendo com que, a cada evento pluviométrico significativo, o fluxo hídrico estabeleça um novo percurso preferencial.

Os trechos de maior representatividade da planície aluvial situam-se na foz do Riacho da Cruz e na foz do Riacho da Várzea. Contudo, no primeiro caso, a planície é larga com trechos onde o canal de drenagem apresenta anastomoses e leques de desague na sua confluência com o riacho dos Ferreiros (Figura 12). No segundo caso, a planície aluvial é estreita, porém alongada, desenvolvendo-se sobre o contato entre metassedimentos e granitos (Figura 13). As intervenções humanas sobre a dinâmica do relevo nas duas bacias hidrográficas são diversificadas, especialmente quanto ao uso das terras. Entretanto, considerou-se que as atividades com maiores impactos no sistema geomorfológico são as atividades de extração de granito, nas pedreiras, para construção civil e pavimentação de vias urbanas, além dos barramentos dos açudes (Figura 14) e as cacimbas (Figura 15), escavadas nos leitos dos canais de drenagem e/ou nas planícies aluviais.

Por se tratar de áreas inseridas no semiárido, com quantidade significativa de população vivendo na zona rural, dependendo da água pluvial para o desenvolvimento de diversas atividades econômicas, a quantidade de pequenos barramentos e cacimbas em um único canal de drenagem pode ser considerada elevada. Essas interferências influenciam na dinâmica do relevo, retendo sedimentos nas áreas represadas, dificultando a alimentação das planícies aluviais situadas posteriormente às áreas de retenção. 


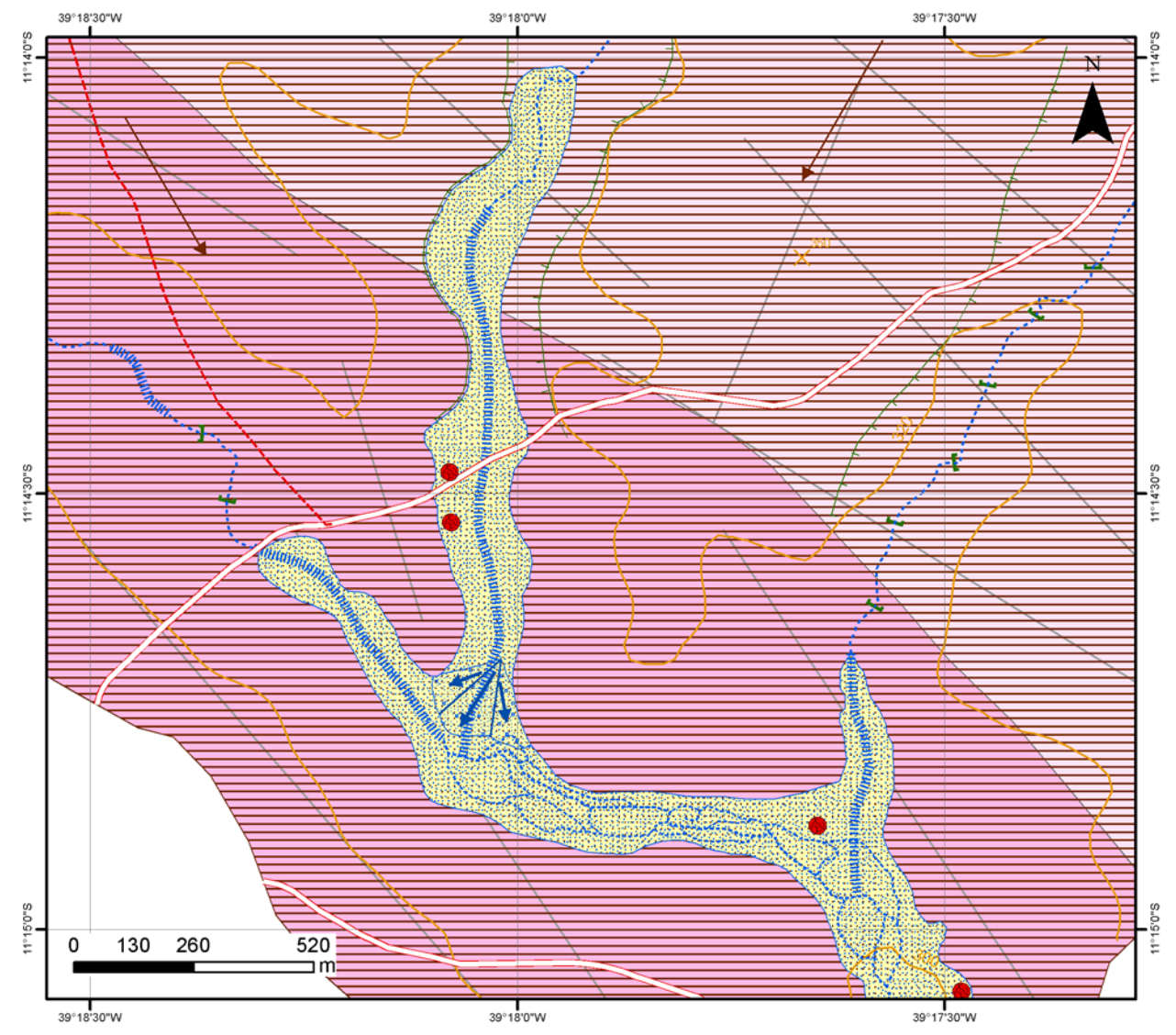

Figura 12. Mapa geomorfológico da planície aluvial situada na foz do Riacho da Cruz. A legenda encontra-se na Figura 6.

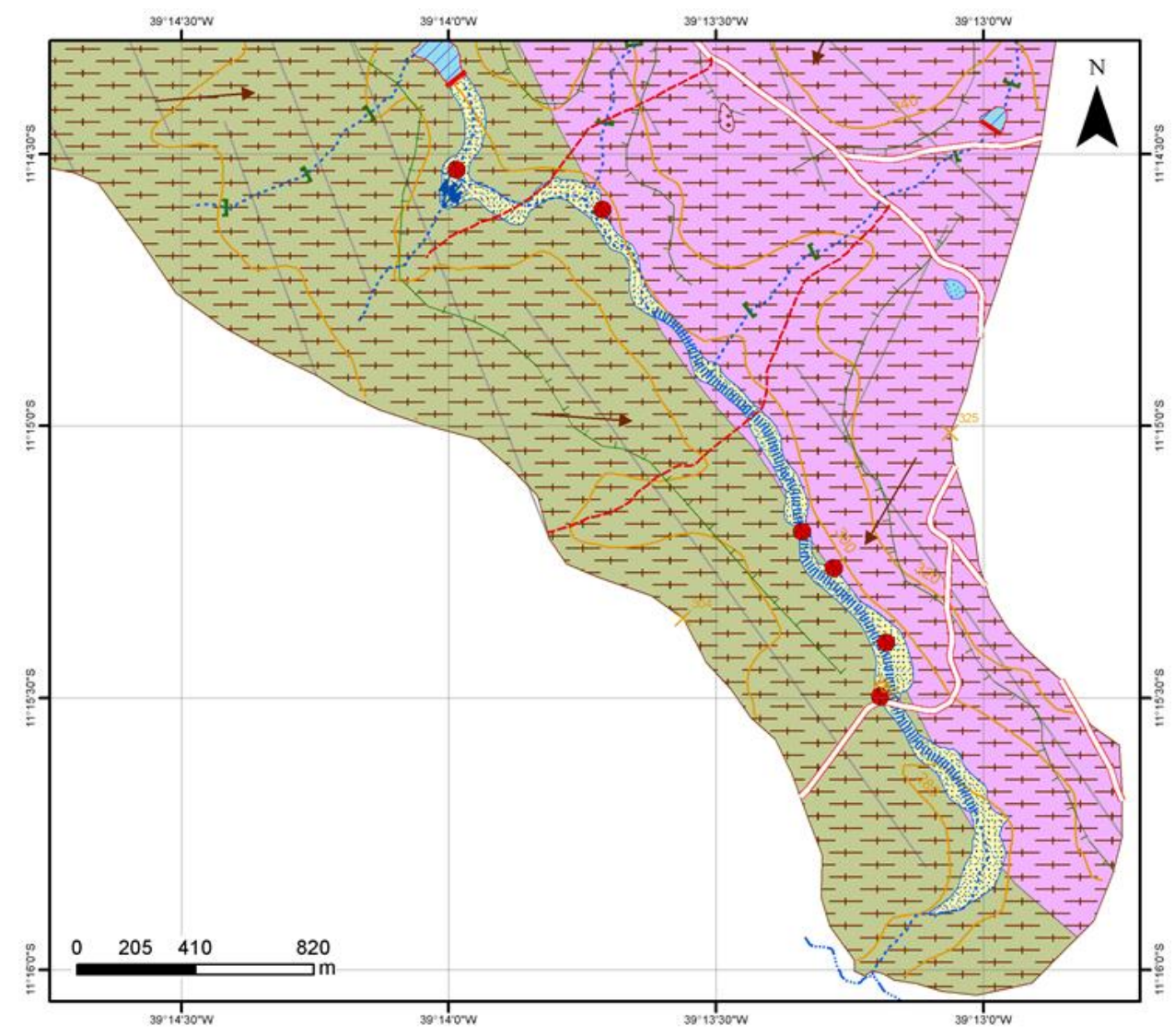

Figura 13. Mapa geomorfológico da planície aluvial situada na foz do Riacho da Várzea. A legenda encontra-se na Figura 6. 


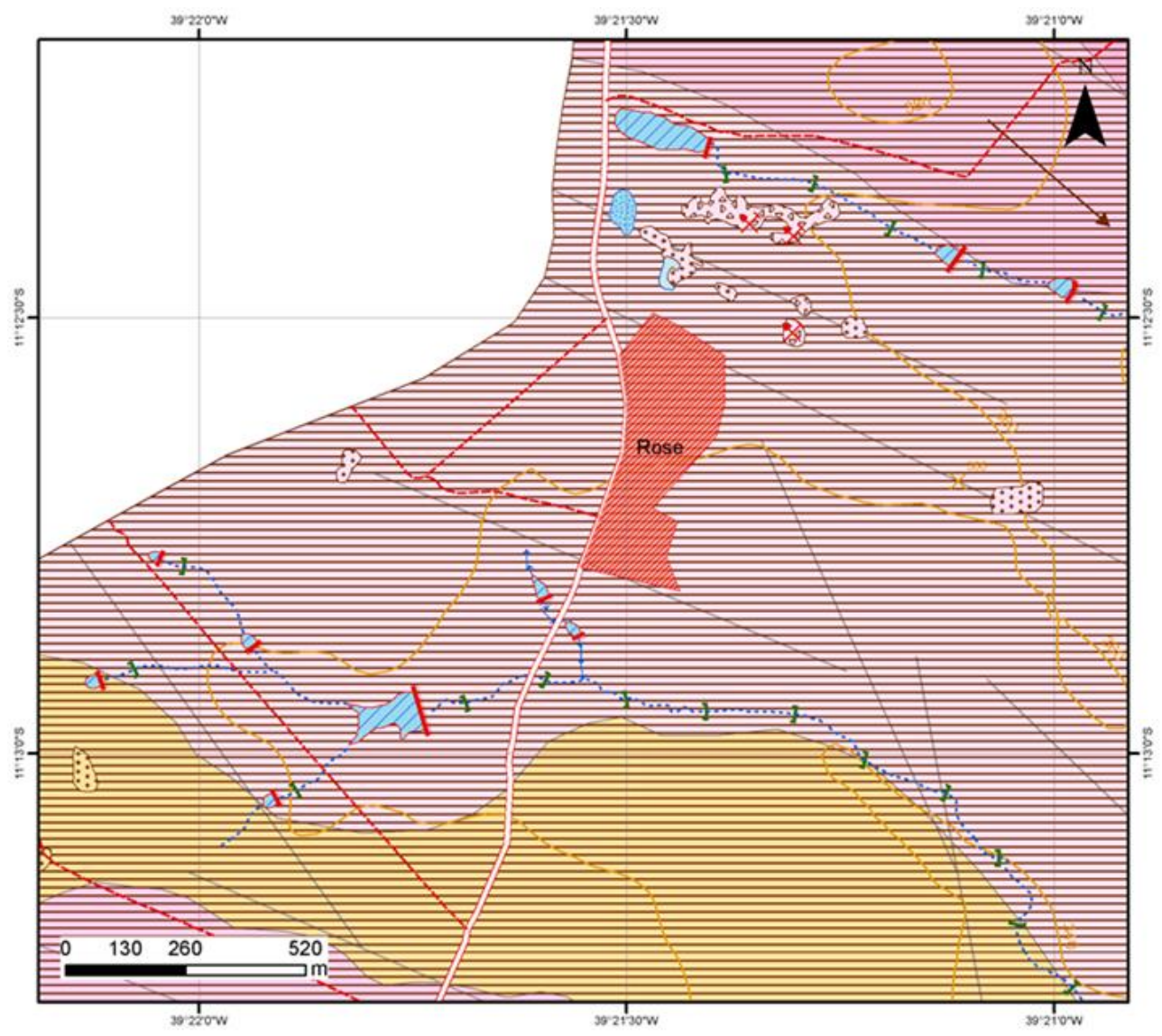

Figura 14. Trecho do mapa geomorfológico da BHRC com destaque para os pequenos barramentos e pedreiras. A legenda encontra-se na Figura 6.

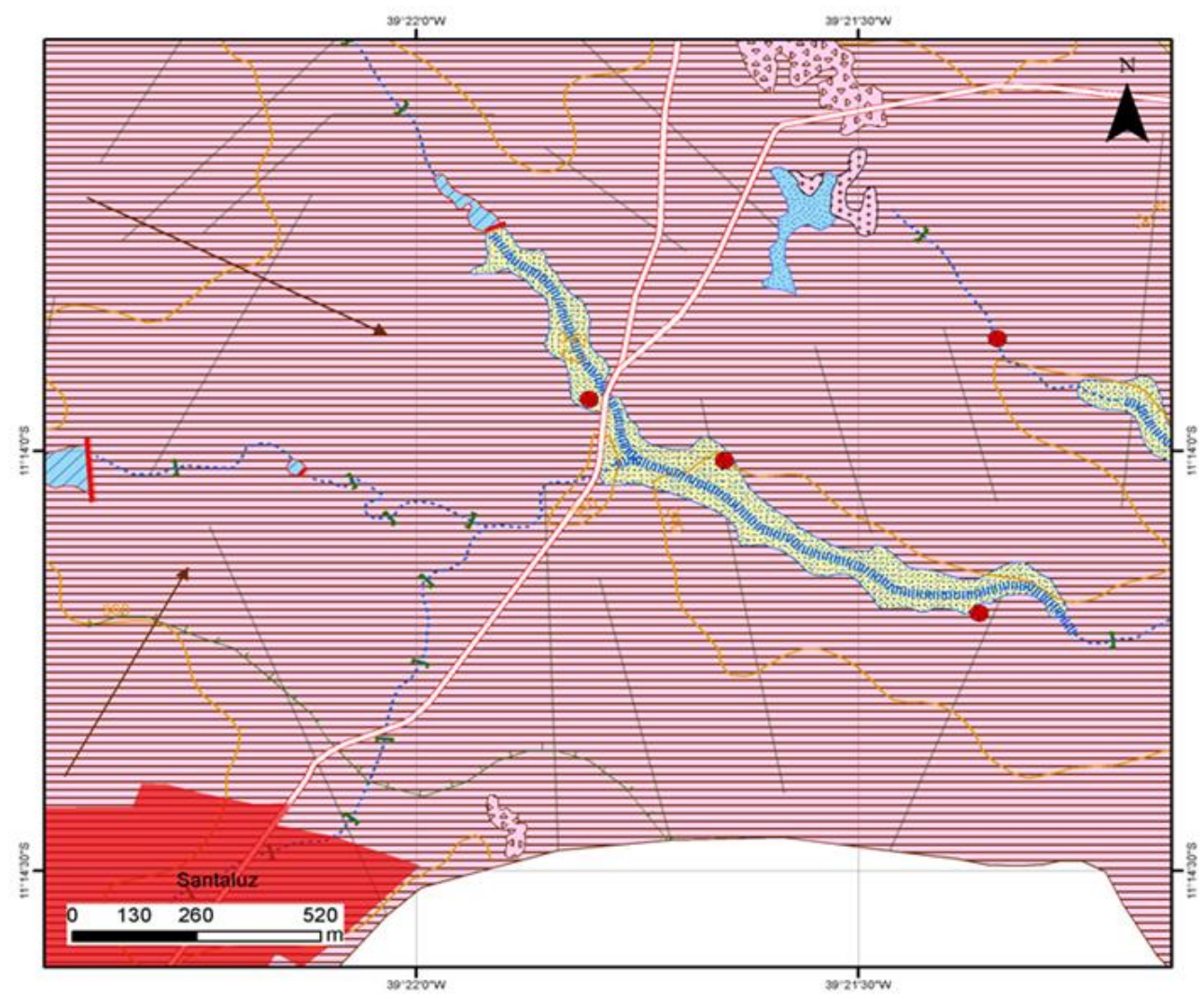

Figura 15. Trecho do mapa geomorfológico da BHRC com destaque para cacimbas escavadas no leito do canal de drenagem e na planície aluvial. A legenda encontra-se na Figura 6. 


\section{Conclusões}

A proposta apresentada nesse artigo partiu do pressuposto de que a cartografia do relevo é um documento importante para a realização de estudos de caráter geomorfológico, independentemente do seu contexto ambiental de desenvolvimento, onde a representação gráfica dos seus elementos não se constitua um fim em si mesma. Dessa maneira, recomenda-se que a realização de mapeamentos geomorfológicos se inicie com o conhecimento teórico e prático das formas a serem mapeadas, no sentido de evitar erros de intepretação.

No contexto do semiárido brasileiro, espera-se contribuir com o desenvolvimento de pesquisas geomorfológicas nesse cenário, tendo em vista a necessidade de levantamentos cartográficos de maior detalhe e estudos sobre o modelado em escalas locais. Assim, considera-se que essa metodologia pode auxiliar no desenvolvimento de estudos em áreas semiáridas com diferentes características, sendo adaptada de acordo com as especificidades de estruturais de cada terreno. Sugere-se ainda que essa proposta seja testada em softwares disponibilizados gratuitamente na rede, no sentido de avaliar o potencial de utilização destes para o mapeamento geomorfológico de maior detalhe que, por si só, possui diversas necessidades de adaptação de simbologias e legenda em ambiente SIG.

Contribuições dos Autores: K. C. L. participou de todas as etapas de desenvolvimento desse trabalho, uma vez que o manuscrito apresentou parte dos resultados obtidos em seu estágio de pós-doutoramento. C. M. L. participou da concepção metodológica, escrita do artigo, revisão e supervisão da pesquisa. Todos os autores leram e concordaram com a versão publicada do manuscrito.

Financiamento: Esta pesquisa foi financiada pelo Programa Nacional de Pós-Doutorado da Coordenação de Aperfeiçoamento de Pessoal de Nível Superior (PNPD/CAPES), bolsa n 88882.317847/2019-01, por meio do Programa de Pós-Graduação em Geografia da Universidade Estadual Paulista "Júlio de Mesquita Filho", campus de Rio Claro - SP.

Agradecimentos: Os autores agradecem aos professores Dra. Liliane Matos Góes (Universidade do Estado da Bahia - UNEB, campus de Jacobina) e ao Dr. Sirius de Oliveira Souza (Universidade Federal do Vale do São Francisco - UNIVASF, campus de Senhor do Bonfim - BA), pelo suporte nos trabalhos de campo.

Conflito de Interesse: Os autores declaram não haver conflito de interesse. Os financiadores não tiveram interferência no desenvolvimento do estudo; na coleta, análise ou interpretação dos dados; na redação do manuscrito, ou na decisão de publicar os resultados.

\section{Referências}

1. CUNHA, C. M. L. A cartografia geomorfológica em áreas litorâneas. Tese (Livre-docência) - Instituto de Geociências e Ciências Exatas, Universidade Estadual Paulista "Júlio de Mesquita Filho", Rio Claro, 2011. 119p.

2. FERREIRA, B. A região semiárida nordestina: utilização dos dados SRTM para mapeamento geomorfológico de parte dos municípios de Jatobá Petrolândia e Tacaratu, Sub-Médio São Francisco, PE. Ciência e Natura, Santa Maria, v. 32, n. 1, p. 143 - 158, 2010. DOI: 10.5902/2179460X9503

3. GRAF, W.L. Fluvial processes in Dryland Rivers. Berlin: Spring-Verlag, 1988. 346 p.

4. GUSTAVSSON, M.; KOLSTRUP, E.; SEIJMONSBERGEN, A. C. A new symbol-and-GIS- based detailed geomorphological mapping system: renewal of a scientific discipline for understanding landscape development. Geomorphology, 77, p. 90-111, 2006. DOI: 10.1016/j.geomorph.2006.01.026

5. IBGE. Manual Técnico de Geomorfologia. Rio de Janeiro: IBGE, Coordenação de Recursos Naturais e Estudos Ambientais. 2. ed., 2009.

6. LIMA, K. C.; CUNHA, M. C. L.; PEREZ FILHO, A. Dificuldades e possibilidades da cartografia geomorfológica no semiárido brasileiro. Revista Brasileira de Cartografia, n. 65, v. 6, p. 1063-1073, 2013.

7. LIMA, K. C.; CUNHA, C. M. L. Atualização Cartográfica da rede de drenagem para estudo geomorfológico de rios intermitentes e efêmeros no semiárido. Revista Brasileira de Cartografia, v. 66, n. 1, p. 127-136, 2014.

8. LIMA, G. G. Análise comparativa de metodologias de mapeamento geomorfológico na bacia do rio Salamanca, Cariri Cearense. Dissertação (Mestrado em Geografia) - Centro de Ciências Humanas e Filosofia, Universidade Federal de Pernambuco, Recife, 2014. $122 \mathrm{f}$.

9. LIMA, F. J.; LIMA, G. G; CORREA, A. C. B.; MARÇAL, M. S. Mapeamento geomorfológico em escala de semi-detalhe e a flexibilização de manuais de mapeamento: breves considerações a partir de um estudo de caso - setor subúmido do planalto sedimentar do Araripe/CE/Brasil. Ensaios de Geografia, v. 3, p. 61-78, 2014.

10. LIMA, K. C.; LUPINACCI, C. M. Cartografia de alterações antrópicas em redes de drenagem semiáridas: possibilidades de avaliação por meio de imagens. Google EarthTM. Ar@cne, nº 237, p. 1-18, diciembre de 2019. 
11. MARENGO, J. A.; CUNHA, A. P.; ALVES, L. M. A seca de 2012-15 no semiárido do Nordeste do Brasil no contexto histórico. Climanálise, v. 3, p. 1-6, 2016.

12. OTTO, J. C.; GUSTAVSSON, M.; GEILHAUSEN, M. Cartography: design, symbolization and visualization of geomorphological maps. In: SMITH, M. J.; PARON, P.; GRIFFITHS, J. S. (Ed.). Geomorphological mapping: methods and applications. Amsterdam: Elsevier, 2011. p. 253-295.

13. PASCHOAL, L. G.; CONCEIÇÃO, F. T.; CUNHA, C. M. L. Utilização do ArcGis 9.3 na elaboração de simbologias para mapeamentos geomorfológicos: uma aplicação na área do complexo argileiro de Santa Gertrudes/SP. In: VIII Simpósio Nacional de Geomorfologia e I Encontro Ibero Americano de Geomorfologia, 8., 2010, Recife. Anais... Brasília: União de Geomorfologia Brasileira. 2010. p. 1-13.

14. PAVLOPOULOS, K.; EVELPIDOU, N.; VASSILOPOULOS, A. Mapping geomorphological environments. BerlinHeidelberg: Springer-Verlag, 2009, $247 \mathrm{p}$.

15. CPRM. Programa levantamentos geológicos básicos do Brasil. Carta geológica - Escala 1: 250.000 (Folha Serrinha SC.24-Y-D). 2010.

16. SILVA, T. C. Contribuição da geomorfologia ao estudo dos ambientes da caatinga. In: Simpósio sobre a caatinga e sua exploração racional, 1., 1986, Feira de Santana. Anais... São Paulo: EMBRAPA/DDI. 1986. p. 49-71.

17. SOUZA, T. A.; OLIVEIRA, R. C. Avaliação da potencialidade de imagens tridimensionais em meio digital para o mapeamento geomorfológico. Revista Geonorte, edição especial, v. 2, n. 4, p. 1348 - 1355, 2012.

18. SEI. Balanço hídrico do estado da Bahia. Salvador: SEI, 1999.

19. TRICART, J. Principles et méthodes de la géomorphologie. Paris: Masson, 1965. 496 p.

20. VERSTAPPEN, H. T.; ZUIDAM, R. A. V. ITC System of geomorphological survey. 3. ed., Enschede: ITC, Vol. VII, 1975. $52 \mathrm{p}$.

Esta obra está licenciada com uma Licença Creative Commons Atribuição 4.0 Internacional (http://creativecommons.org/licenses/by/4.0/) - CC BY. Esta licença permite que outros distribuam, remixem, adaptem e criem a partir do seu trabalho, mesmo para fins comerciais, desde que lhe atribuam o devido crédito pela criação original. 